\title{
Ion chemistry in premixed rich methane flames
}

\author{
Bingjie Chen ${ }^{a^{*}}$, Haoyi Wang ${ }^{\text {a }}$, Zhandong Wang ${ }^{\text {a }}$, Jie Han ${ }^{\mathrm{a}}$, Awad B.S. Alquaity ${ }^{\mathrm{a}, \mathrm{b}}$, Heng Wang \\ ${ }^{\mathrm{a}}$, Nils Hansen ${ }^{\mathrm{c}}$, S. Mani Sarathy ${ }^{\mathrm{a*}}$ \\ a King Abdullah University of Science and Technology (KAUST), Clean Combustion Research Center (CCRC), \\ Thuwal 23955-6900, Saudi Arabia \\ c Institute for Combustion Technology, RWTH Aachen University, Templergraben 64, 52062 Aachen, Germany \\ c Combustion Research Facility, Sandia National Laboratory, Livermore, CA, 94551, USA
}

\begin{abstract}
:
External electric field and plasma assisted combustion show great potential for combustion enhancement, e.g. emission and ignition control. To understand soot suppression by external electric fields and flame ignition in spark ignition engines, flame ion chemistry needs to be investigated and developed. In this work, comprehensive and systematic investigations of neutral and ion chemistry are conducted in premixed rich methane flames. Cations are measured by quadrupole molecular beam mass spectrometry (MBMS), and neutrals are measured by synchrotron vacuum ultra violet photoionization time of flight MBMS (SVUV-PI-TOF-MBMS). The molecular formula and dominant isomers of various measured cations are identified based on literature survey and quantum chemistry calculations. Experimentally, we found that $\mathrm{H}_{3} \mathrm{O}^{+}$is the dominant cation in slightly rich flame $(\phi=1.5)$, but $\mathrm{C}_{3} \mathrm{H}_{3}{ }^{+}$is the most significant in very rich flames $(\phi=1.8$ and 2.0). An updated ion chemistry model is proposed and used to explain the effects of changing equivalence ratio. To further verify key ion-neutral reaction pathways, measured neutral profiles are compared with cation profiles experimentally. Detailed cation and neutral
\end{abstract}

\footnotetext{
*Corresponding authors email: bingjie.chen@kaust.edu.sa (B.Chen), mani.sarathy@kaust.edu.sa (S.M.Sarathy)
} 
measurements and numerical simulations by this work help to understand and develop ion chemistry models. Deficiencies in our current understanding of ion chemistry are also highlighted to motivate further research.

Keywords: Ion chemistry, dominant cation, quadrupole molecular beam mass spectrometry, photo-ionization molecular beam mass spectrometry, premixed rich methane flame.

\section{Introduction}

Ions are widely present in flames. They are produced by chemi-ionization reactions leading to ion mole fraction from $10^{-7}$ to $10^{-9}$ [1]. Ion sensors are used for spark ignition [2], knock control [3] and in-cylinder pressure regulation [4] in internal combustion engines. For decades, ion measurements helped study neutral chemistry in flames [5-10]. Moreover, external electric field and plasma assisted combustion have demonstrated the opportunity of combustion enhancement, e.g. soot suppression [11], flame stability extension [6] and combustion efficiency improvement. To realize and manage electric field applications on combustion systems, ion chemistry models need to be understood and developed.

The main challenge for measuring ions in flames is that their mole fractions are very low, inhibiting non-intrusive laser diagnostics measurements. Molecular beam mass spectrometry (MBMS) has been used to provide high fidelity ion measurements for decades [1]. MBMS was used to measure ions in acetylene flames by Deckers et al. [9, 10] and Hayhurst et al.[12, 13]; ethylene flames by Colcate et al. [5]; methane flames by Goodings et al. [7, 8] and Jones et al. [14]; and propane flames by Fialkov et al. [15]. Measurements in Goodings et al. [7, 8] were performed in conical flames sustained by a quartz burner, which does not provide an ideal onedimensional flame, hampering the development of ion chemistry models. Recently, Alquaity et al. 
$[16,17]$ measured cations in premixed methane flames sustained by a McKenna burner. Their measurements showed that $\mathrm{H}_{3} \mathrm{O}^{+}$was the dominant cation in lean and stoichiometric flames, and comparable with predictions of a numerical model by Prager et al. [18]. However in rich flames, the dominant cation changes to $\mathrm{C}_{3} \mathrm{H}_{3}{ }^{+}$, as observed by Jones et al. [14] and predicted by Peterson et al. [19]. This suggests different ion chemistry in rich flames compared to lean and stoichiometric flames. Differing ion chemistry mechanisms under varying conditions drive the need for more experimental data and model development in rich flames, which is the focus of this work.

This paper presents a systematic and comprehensive ion chemistry investigation on rich premixed methane flames. A McKenna burner is used to sustain one-dimensional premixed flames, which is more ideal than the Bunsen burners used in previous literature $[7,8,14]$. First, cations are detected and measured by quadrupole MBMS, and their chemical formula are determined by literature review $[13,16]$ and quantum chemistry calculations. $\mathrm{H}_{3} \mathrm{O}^{+}$is observed as the dominant cation in slightly rich flames, while $\mathrm{C}_{3} \mathrm{H}_{3}{ }^{+}$becomes the dominant ion in richer flames. Next, an updated ion chemistry mechanism is proposed to explain the observed cation trends with varying equivalence ratios. Finally, neutral profiles in one flame are measured by Synchrotron Vacuum Ultra Violet Photo Ionization Time of Flight MBMS (SVUV-PI-TOF-MBMS) to provide further validation of proposed ion chemistry pathways. These new measurements and kinetic modeling may provide better insights on soot suppression by electric fields and plasma assisted combustion by improving our understanding of ion chemistry. 


\section{Methodology}

\subsection{Cation measurements by quadrupole MBMS}

Ion profiles were measured by quadrupole MBMS at KAUST. The experimental setup has been described in previous work [16]. A general description is given here with a few modifications specific to this work. A stainless water-cooled McKenna burner was utilized to establish burner stabilized premixed methane/oxygen/argon flames. Cooling water temperature was fixed at $25 \mathrm{C}$. Gas flow rates were regulated by calibrated MKS mass flow controllers with uncertainty of $1 \%$ of the full range (5 SLPM). The McKenna burner is mounted on a high-resolution translation stage (SMC, LEY- 25RC-350G-S5) with positioning uncertainty of $\pm 0.01 \mathrm{~mm}$. A Hiden HPR-60 quadrupole MBMS (EQP, $300 \mathrm{~m} / \mathrm{z}$ range) was employed to measure cation profiles as a function of height above burner (HAB). A $24 \mathrm{~mm}$ long nickel cone of 45 degrees cone angle was utilized to sample cations directly from flames. A metallic cone was used to facilitate ion transfer from the flames into the MBMS. No electron impact ionization energy was applied, so neutrals were not detected. The 45 degree sampling cone used in this work has a smaller cone angle than the 57 degree cone utilized in the previous work [16], in order to reduce sampling disturbances [20], which have been found to be more prominent for rich flames [16]. The effects of sampling cone angle on measured ion signals is presented in Figure S1 and discussed in Supplementary Material1. After sampling, three stages of differential pumping are employed to create a pressure gradient and form a molecular beam. Electrical potentials are applied on the second and third sampling stage cones to direct the cations towards the MS, where cations are identified by quadrupole mass filter and quantified by the detector. 
Mass scans were first performed to find cations with detectable signals, and then quadrupole MBMS ion transmission energy scans on each cation were conducted and integrated to obtain total signals. The total signal for each cation is scaled by a Mass Discrimination Factor (MDF) and instrument specific sampling transfer function [21]. MDF was determined by sampling a calibration gas of known composition at the same first stage pressure as the sampled flames. Details on MDF calibration can be found in literature [17], and the MDF calibration curve obtained in this work is presented in Figure S2 in Supplementary Material-1. The overall uncertainty (repeatability) of measurements is estimated to be $20 \%$, obtained by triplicate measurements.

Four flames were chosen as target flames in this work, and their conditions are presented in Table 1. Cations in flames A, B and C were measured in this work, and flame D was reported in previous work [16]. Different flame pressures were chosen at different equivalence ratios to maintain a stable flame, which can permit complete cation profiles consisting of initial appearance, maximum, and eventual decay. Flame temperature is measured by a $\mathrm{SiO}_{2}$ coated B-type thermocouple (Omega) with a bead size of $0.60 \mathrm{~mm}$ after coating to minimize catalytic effects on temperature measurement. The measured temperature was corrected for radiation effects using the correction relation from Shaddix et al. [22].

Table 1 Premixed rich methane flame experimental conditions.

\begin{tabular}{cccccc}
\hline \multirow{2}{*}{ Flames } & \multirow{2}{*}{$\phi$} & \multirow{2}{*}{ Pressure (torr) } & \multicolumn{3}{c}{ Flow rates (sccm) } \\
& & & $\mathrm{CH}_{4}$ & $\mathrm{O}_{2}$ & $\mathrm{Ar}$ \\
\hline $\mathrm{A}$ & 1.5 & 20.0 & 1607 & 2143 & 1250 \\
$\mathrm{~B}$ & 1.8 & 45.0 & 1776 & 1974 & 1250 \\
$\mathrm{C}$ & 2.0 & 70.0 & 1875 & 1875 & 1250 \\
$\mathrm{D}$ & 1.5 & 30.0 & 1607 & 2143 & 1250 \\
\hline
\end{tabular}




\subsection{Neutral measurements by SVUV-PI-TOF-MBMS}

Neutral measurements of flame D were performed by SVUV-PI-TOF-MBMS at the Chemical Dynamic Beamline 9.0.2 in Advanced Light Source, Lawrence Berkeley National Laboratory. The experimental setup is described in previous work [23] and a brief description is given here. Gases from premixed methane flames are sampled through a quartz probe, and directed through two stages of differential pumping to form a molecular beam and enable MS detection. The quartz probe isolates and prevents flame ions from being transferred into the MBMS. After sampling, a tunable vacuum ultraviolet beam $\left(10^{13}\right.$ photons/s, energy resolution $0.05 \mathrm{eV}$, range from 8.00 to $17.00 \mathrm{eV}$ ) generated by synchrotron radiation is used to "softly" ionize neutrals without breaking their chemical bonds. Generated ions are then registered and quantified by TOF-MS (mass resolution 4000). One benefit of photo-ionization mass spectrometry is the ability to separate isomers. For example, $\mathrm{C}_{3} \mathrm{H}_{4}$ has three isomers: allene, propyne and cyclopropene. They cannot be distinguished by conventional electron-ionization mass spectrometry because of identical chemical formula, but their different photo ionization energies make experimental identification possible. Allene has onset photo-ionization energy at $9.69 \mathrm{eV}$, propyne at $10.30 \mathrm{eV}$, and cyclopropene at $9.67 \mathrm{eV}$. The measured PIE curve for $\mathrm{C}_{3} \mathrm{H}_{4}$ (results appear in Figure S3 in Supplementary Material-1) has an onset at $9.69 \mathrm{eV}$ and turning point at $10.30 \mathrm{eV}$, which corresponds to allene and propyne onset photo-ionization energies. Cyclopropene is not assigned because it is less likely to be produced in methane flames.

Methods on converting signals to mole fractions can be found in literature [24-26]. Detailed calculation processes used in this work are presented in Supplementary Material-1. The overall uncertainty of major species measurements is estimated to be $15 \%$ [27]. For intermediates and radicals, the uncertainty is up to $30 \%$ due to uncertainty from photo ionization cross section. 


\subsection{Numerical simulations}

\subsubsection{Proposed ion chemistry mechanism}

The proposed ion chemistry mechanism was developed based on our previous work [16] with two updates. First, AramcoMech 2.0 $\mathrm{C}_{0}-\mathrm{C}_{4}$ mechanism [28] is used as the base model for neutral species. Second, additional reactions of $\mathrm{CH}_{3}{ }^{+}$and $\mathrm{C}_{3} \mathrm{H}_{3}{ }^{+}$from UMIST database [29] and available literature $[30,31]$ were added. The proposed ion chemistry model has larger neutral base model and ion-neutral reactions than that of Peterson et al. [19]. A complete set of reactions is listed in Table 2.

Table 2 Reaction mechanism of charged species for rich methane flames

\begin{tabular}{|c|c|c|c|c|c|}
\hline Index & Reactions & $\begin{array}{c}\mathrm{A} \\
\text { (cm3/mol-sec) }\end{array}$ & $\mathrm{n}$ & $\begin{array}{c}E \\
\text { (cal/mol) }\end{array}$ & Ref \\
\hline \multicolumn{6}{|c|}{ Positive ion (Cation) reactions } \\
\hline 1 & $\mathrm{CH}+\mathrm{O}<=>\mathrm{HCO}^{+}+\mathrm{E}^{-\mathrm{a}}$ & $2.51 \mathrm{E}+11$ & 0 & 1700 & [18] \\
\hline 2 & $\mathrm{HCO}^{+}+\mathrm{H}_{2} \mathrm{O} \Leftrightarrow=>\mathrm{H}_{3} \mathrm{O}^{+}+\mathrm{CO}$ & $2.60 \mathrm{E}+16$ & -0.5 & 0 & [29] \\
\hline 3 & $\mathrm{H}_{3} \mathrm{O}^{+}+\mathrm{E}^{-}<=>\mathrm{H}_{2} \mathrm{O}+\mathrm{H}$ & $2.29 \mathrm{E}+18$ & -0.5 & 0 & [18] \\
\hline 4 & $\mathrm{H}_{3} \mathrm{O}^{+}+\mathrm{E}^{-}<=>\mathrm{OH}+\mathrm{H}+\mathrm{H}$ & $7.95 E+21$ & -1.37 & 0 & [18] \\
\hline 5 & $\mathrm{H}_{3} \mathrm{O}^{+}+\mathrm{E}^{-}<=>\mathrm{H}_{2}+\mathrm{OH}$ & $1.25 \mathrm{E}+19$ & -0.5 & 0 & [18] \\
\hline 6 & $\mathrm{H}_{3} \mathrm{O}^{+}+\mathrm{E}^{-}<=>\mathrm{O}+\mathrm{H}_{2}+\mathrm{H}$ & $6.00 \mathrm{E}+17$ & -0.3 & 0 & [18] \\
\hline 7 & $\mathrm{HCO}^{+}+\mathrm{E}^{-}<=>\mathrm{CO}+\mathrm{H}$ & $7.40 \mathrm{E}+18$ & -0.68 & 0 & [29] \\
\hline 8 & $\mathrm{HCO}^{+}+\mathrm{C}_{2} \mathrm{H}_{5} \mathrm{OH} \Leftrightarrow=>\mathrm{H}_{3} \mathrm{O}^{+}+\mathrm{CO}+\mathrm{C}_{2} \mathrm{H}_{4}$ & $6.00 \mathrm{E}+14$ & 0 & 0 & [29] \\
\hline 9 & $\mathrm{H}_{3} \mathrm{O}^{+}+\mathrm{C}<=>\mathrm{HCO}^{+}+\mathrm{H}_{2}$ & $6.02 \mathrm{E}+12$ & 0 & 0 & [29] \\
\hline 10 & $\mathrm{HCO}^{+}+\mathrm{CH}_{2} \mathrm{CO} \Leftrightarrow=>\mathrm{C}_{2} \mathrm{H}_{3} \mathrm{O}^{+}+\mathrm{CO}$ & $1.88 \mathrm{E}+16$ & -0.05 & 0 & [29] \\
\hline 11 & $\mathrm{HCO}^{+}+\mathrm{CH}_{3}<=>\mathrm{C}_{2} \mathrm{H}_{3} \mathrm{O}^{+}+\mathrm{H}$ & $7.76 \mathrm{E}+14$ & -0.01 & 0 & [29] \\
\hline 12 & $\mathrm{C}_{2} \mathrm{H}_{3} \mathrm{O}^{+}+\mathrm{E}^{-}<=>\mathrm{CH}_{2} \mathrm{CO}+\mathrm{H}$ & $3.13 \mathrm{E}+18$ & -0.5 & 0 & [29] \\
\hline 13 & $\mathrm{H}_{3} \mathrm{O}^{+}+\mathrm{CH}_{2} \mathrm{CO} \Leftrightarrow=>\mathrm{C}_{2} \mathrm{H}_{3} \mathrm{O}^{+}+\mathrm{H}_{2} \mathrm{O}$ & $1.20 \mathrm{E}+15$ & 0 & 0 & [18] \\
\hline 14 & $\mathrm{C}_{2} \mathrm{H}_{3} \mathrm{O}^{+}+\mathrm{E}^{-}<=>\mathrm{CO}+\mathrm{CH}_{3}$ & $3.13 E+18$ & -0.5 & 0 & [29] \\
\hline 15 & $\mathrm{C}_{2} \mathrm{H}_{3} \mathrm{O}^{+}+\mathrm{O} \Leftrightarrow=>\mathrm{HCO}^{+}+\mathrm{CH}_{2} \mathrm{O}$ & $2.00 \mathrm{E}+14$ & 0 & 0 & [29] \\
\hline 16 & $\mathrm{HCO}^{+}+\mathrm{CH}_{3} \mathrm{OH}<=>\mathrm{CH}_{5} \mathrm{O}^{+}+\mathrm{CO}$ & $2.82 E+16$ & -0.5 & 0 & [29] \\
\hline 17 & $\mathrm{H}_{3} \mathrm{O}^{+}+\mathrm{CH}_{3} \mathrm{OH}<=>\mathrm{CH}_{5} \mathrm{O}^{+}+\mathrm{H}_{2} \mathrm{O}$ & $2.61 \mathrm{E}+16$ & -0.5 & 0 & [29] \\
\hline 18 & $\mathrm{CH}_{5} \mathrm{O}^{+}+\mathrm{E}^{-}<=>\mathrm{CH}_{3} \mathrm{OH}+\mathrm{H}$ & $4.65 \mathrm{E}+17$ & -0.59 & 0 & [29] \\
\hline 19 & $\mathrm{CH}+\mathrm{C}_{2} \mathrm{H}_{2}=>\mathrm{C}_{3} \mathrm{H}_{3}^{+}+\mathrm{E}^{-}$ & $1.00 \mathrm{E}+10$ & 0 & 10000 & [30] \\
\hline 20 & $\mathrm{CH}^{* \mathrm{~b}}+\mathrm{C}_{2} \mathrm{H}_{2}<=>\mathrm{C}_{3} \mathrm{H}_{3}^{+}+\mathrm{E}^{-}$ & $2.00 \mathrm{E}+11$ & 0 & 0 & [31] \\
\hline 21 & $\mathrm{O}+\mathrm{C}_{3} \mathrm{H}_{3}^{+}<=>\mathrm{HCO}^{+}+\mathrm{C}_{2} \mathrm{H}_{2}$ & $1.20 \mathrm{E}+15$ & 0 & 0 & [29] \\
\hline 22 & $\mathrm{CH}_{2}+\mathrm{HCO}^{+}<=>\mathrm{CO}+\mathrm{CH}_{3}^{+}$ & $5.18 \mathrm{E}+15$ & 0 & 0 & [29] \\
\hline
\end{tabular}




\begin{tabular}{|c|c|c|c|c|c|}
\hline 23 & $\mathrm{CH}_{3}^{+}+\mathrm{HCO}<=>\mathrm{HCO}^{+}+\mathrm{CH}_{3}$ & $4.59 E+16$ & -0.5 & 0 & [29] \\
\hline 24 & $\mathrm{CH}_{3}^{+}+\mathrm{CH}_{2} \mathrm{O} \Leftrightarrow=\mathrm{HCO}^{+}+\mathrm{CH}_{4}$ & $1.67 \mathrm{E}+17$ & -0.5 & 0 & [29] \\
\hline 25 & $\mathrm{CH}_{3}^{+}+\mathrm{O} \Leftrightarrow=>\mathrm{HCO}^{+}+\mathrm{H}_{2}$ & $2.41 \mathrm{E}+15$ & 0 & 0 & [29] \\
\hline 26 & $\mathrm{CH}_{2}+\mathrm{H}_{3} \mathrm{O}^{+}<=>\mathrm{H}_{2} \mathrm{O}+\mathrm{CH}_{3}^{+}$ & $5.66 \mathrm{E}+15$ & 0 & 0 & [29] \\
\hline 27 & $\mathrm{H}_{3} \mathrm{O}^{+}+\mathrm{C}_{3} \mathrm{H}_{2} \Leftrightarrow=>\mathrm{C}_{3} \mathrm{H}_{3}^{+}+\mathrm{H}_{2} \mathrm{O}$ & $3.13 \mathrm{E}+17$ & -0.5 & 0 & [29] \\
\hline 28 & $\mathrm{CH}_{3}{ }^{+}+\mathrm{C}_{2} \mathrm{H}_{3}<=>\mathrm{C}_{3} \mathrm{H}_{3}{ }^{+}+\mathrm{H}_{2}+\mathrm{H}$ & $1.04 \mathrm{E}+16$ & -0.5 & 0 & [29] \\
\hline 29 & $\mathrm{C}_{3} \mathrm{H}_{3}^{+}+\mathrm{E}^{-}<=>\mathrm{C}_{3} \mathrm{H}_{2}+\mathrm{H}$ & $7.30 \mathrm{E}+19$ & -0.5 & 0 & [29] \\
\hline 30 & $\mathrm{CH}_{3}^{+}+\mathrm{C}_{2} \mathrm{H}_{2} \Leftrightarrow=>\mathrm{C}_{3} \mathrm{H}_{3}^{+}+\mathrm{H}_{2}$ & $2.17 E+15$ & 0 & 0 & [30] \\
\hline 31 & $\mathrm{C}_{3} \mathrm{H}_{3}^{+}+\mathrm{H}_{2} \mathrm{O} \Leftrightarrow>\mathrm{C}_{2} \mathrm{H}_{3} \mathrm{O}^{+}+\mathrm{CH}_{2}$ & $7.24 \mathrm{E}+14$ & 0 & 0 & [30] \\
\hline 32 & $\mathrm{H}_{3} \mathrm{O}^{+}+\mathrm{C}_{2} \mathrm{H}_{2} \Leftrightarrow=\mathrm{C}_{2} \mathrm{H}_{3} \mathrm{O}^{+}+\mathrm{H}_{2}$ & $8.39 E+15$ & 0 & 0 & [30] \\
\hline 33 & $\mathrm{C}_{2} \mathrm{H}_{3} \mathrm{O}^{+}+\mathrm{CH} \Leftrightarrow=\mathrm{C}_{3} \mathrm{H}_{3}^{+}+\mathrm{OH}$ & $3.98 E+14$ & -0.01 & 0 & [31] \\
\hline 34 & $\mathrm{C}_{2} \mathrm{H}_{3} \mathrm{O}^{+}+\mathrm{C}_{2} \mathrm{H}_{2}<=>\mathrm{C}_{3} \mathrm{H}_{3}^{+}+\mathrm{CO}+\mathrm{H}_{2}$ & $6.45 \mathrm{E}+14$ & 0 & 0 & [31] \\
\hline 35 & $\mathrm{CH}_{5} \mathrm{O}^{+}+\mathrm{C}_{2} \mathrm{H}_{2}<=>\mathrm{C}_{3} \mathrm{H}_{3}{ }^{+}+\mathrm{H}_{2} \mathrm{O}+\mathrm{H}_{2}$ & $6.92 \mathrm{E}+14$ & 0 & 0 & [31] \\
\hline \multicolumn{6}{|c|}{ Negative ion (Anion) reactions } \\
\hline 36 & $\mathrm{O}_{2}^{-}+\mathrm{H}_{2}<=>\mathrm{H}_{2} \mathrm{O}_{2}+\mathrm{E}^{-}$ & $6.02 E+14$ & 0 & 0 & [18] \\
\hline 37 & $\mathrm{O}_{2}^{-}+\mathrm{H} \Leftrightarrow=>\mathrm{HO}_{2}+\mathrm{E}^{-}$ & $7.23 E+14$ & 0 & 0 & [18] \\
\hline 38 & $\mathrm{O}_{2}^{-}+\mathrm{OH} \Leftrightarrow=>\mathrm{OH}^{-}+\mathrm{O}_{2}$ & $6.02 \mathrm{E}+13$ & 0 & 0 & [18] \\
\hline 39 & $\mathrm{O}_{2}^{-}+\mathrm{H}<=>\mathrm{OH}^{-}+\mathrm{O}$ & $1.08 \mathrm{E}+15$ & 0 & 0 & [18] \\
\hline 40 & $\mathrm{OH}^{-}+\mathrm{O} \Leftrightarrow=>\mathrm{HO}_{2}+\mathrm{E}^{-}$ & $1.20 \mathrm{E}+14$ & 0 & 0 & [18] \\
\hline 41 & $\mathrm{OH}^{-}+\mathrm{H}<=>\mathrm{H}_{2} \mathrm{O}+\mathrm{E}^{-}$ & $1.08 \mathrm{E}+15$ & 0 & 0 & [18] \\
\hline 42 & $\mathrm{OH}^{-}+\mathrm{C}<=>\mathrm{HCO}+\mathrm{E}^{-}$ & $3.00 E+14$ & 0 & 0 & [18] \\
\hline 43 & $\mathrm{OH}^{-}+\mathrm{CH} \Leftrightarrow=>\mathrm{CH}_{2} \mathrm{O}+\mathrm{E}^{-}$ & $3.00 E+14$ & 0 & 0 & [18] \\
\hline 44 & $\mathrm{OH}^{-}+\mathrm{CH}_{3}<=>\mathrm{CH}_{3} \mathrm{OH}+\mathrm{E}^{-}$ & $6.02 E+14$ & 0 & 0 & [18] \\
\hline 45 & $\mathrm{CO}_{3}^{-}+\mathrm{H} \Leftrightarrow=>\mathrm{OH}^{-}+\mathrm{CO}_{2}$ & $1.02 \mathrm{E}+14$ & 0 & 0 & [18] \\
\hline 46 & $\mathrm{CO}_{3}^{-}+\mathrm{O}<=>\mathrm{O}_{2}^{-}+\mathrm{CO}_{2}$ & $4.60 \mathrm{E}+13$ & 0 & 0 & [18] \\
\hline 47 & $\mathrm{CHO}_{2}^{-}+\mathrm{H} \Leftrightarrow=>\mathrm{CO}_{2}+\mathrm{H}_{2}+\mathrm{E}^{-}$ & $1.16 \mathrm{E}+14$ & 0 & 0 & [18] \\
\hline 48 & $\mathrm{OH}^{-}+\mathrm{HCO} \Leftrightarrow=\mathrm{CHO}_{2}^{-}+\mathrm{H}$ & $2.96 \mathrm{E}+15$ & -0.14 & -105.3 & [18] \\
\hline 49 & $\mathrm{O}^{-}+\mathrm{C}<=>\mathrm{CO}+\mathrm{E}^{-}$ & $3.01 E+14$ & 0 & 0 & [18] \\
\hline 50 & $\mathrm{O}^{-}+\mathrm{H}_{2}<=>\mathrm{OH}^{-}+\mathrm{H}$ & $1.99 \mathrm{E}+13$ & 0 & 0 & [18] \\
\hline 51 & $\mathrm{O}^{-}+\mathrm{CH}_{4}<=>\mathrm{OH}^{-}+\mathrm{CH}_{3}$ & $6.02 E+13$ & 0 & 0 & [18] \\
\hline 52 & $\mathrm{O}^{-}+\mathrm{H}_{2} \mathrm{O}<=>\mathrm{OH}^{-}+\mathrm{OH}$ & $8.43 E+14$ & 0 & 0 & [18] \\
\hline 53 & $\mathrm{O}^{-}+\mathrm{CH}_{2} \mathrm{O} \Leftrightarrow=>\mathrm{OH}^{-}+\mathrm{HCO}$ & $5.60 \mathrm{E}+14$ & 0 & 0 & [18] \\
\hline 54 & $\mathrm{O}^{-}+\mathrm{CH}_{2} \mathrm{O} \Leftrightarrow=\mathrm{CHO}_{2}^{-}+\mathrm{H}$ & $1.31 \mathrm{E}+15$ & 0 & 0 & [18] \\
\hline 55 & $\mathrm{O}^{-}+\mathrm{C}_{2} \mathrm{H}_{6} \Leftrightarrow=\mathrm{C}_{2} \mathrm{H}_{5}+\mathrm{OH}^{-}$ & $6.13 E+15$ & -0.5 & 0 & [18] \\
\hline 56 & $\mathrm{O}^{-}+\mathrm{H}^{\prime} \Leftrightarrow=\mathrm{OH}+\mathrm{E}^{-}$ & $3.01 E+14$ & 0 & 0 & [18] \\
\hline 57 & $\mathrm{O}^{-}+\mathrm{H}_{2}<=>\mathrm{H}_{2} \mathrm{O}+\mathrm{E}^{-}$ & $4.22 \mathrm{E}+14$ & 0 & 0 & [18] \\
\hline 58 & $\mathrm{O}^{-}+\mathrm{CH}<=>\mathrm{HCO}^{-E^{-}}$ & $3.01 E+14$ & 0 & 0 & [18] \\
\hline 59 & $\mathrm{O}^{-}+\mathrm{CH}_{2}<=\mathrm{CH}_{2} \mathrm{O}+\mathrm{E}^{-}$ & $3.01 \mathrm{E}+14$ & 0 & 0 & [18] \\
\hline 60 & $\mathrm{O}^{-}+\mathrm{CO} \Leftrightarrow=>\mathrm{CO}_{2}+\mathrm{E}^{-}$ & $3.91 \mathrm{E}+14$ & 0 & 0 & [18] \\
\hline 61 & $\mathrm{O}^{-}+\mathrm{O} \Leftrightarrow=\mathrm{O}_{2}+\mathrm{E}^{-}$ & $8.43 E+13$ & 0 & 0 & [18] \\
\hline 62 & $\mathrm{O}^{-}+\mathrm{C}_{2} \mathrm{H}_{2}<=>\mathrm{CH}_{2} \mathrm{CO}+\mathrm{E}^{-}$ & $7.23 E+14$ & 0 & 0 & [18] \\
\hline 63 & $\mathrm{O}^{-}+\mathrm{H}_{2} \mathrm{O}=>\mathrm{H}_{2} \mathrm{O}_{2}+\mathrm{E}^{-}$ & $3.61 E+11$ & 0 & 0 & [29] \\
\hline 64 & $\mathrm{O}_{2}^{-}+\mathrm{O}<=>\mathrm{O}^{-}+\mathrm{O}_{2}$ & $1.99 \mathrm{E}+14$ & 0 & 0 & [29] \\
\hline 65 & $\mathrm{O}_{2}^{-}+\mathrm{C}_{2} \mathrm{H}_{3} \mathrm{O}^{+}<=>\mathrm{O}_{2}+\mathrm{CH}_{2} \mathrm{CHO}$ & $2.09 \mathrm{E}+18$ & -0.5 & 0 & [29] \\
\hline
\end{tabular}




\begin{tabular}{|c|c|c|c|c|c|}
\hline 66 & $\mathrm{O}_{2}^{-}+\mathrm{C}_{2} \mathrm{H}_{3} \mathrm{O}^{+}<=>\mathrm{O}_{2}+\mathrm{CH}_{2} \mathrm{CO}+\mathrm{H}$ & $1.00 \mathrm{E}+18$ & 0 & 0 & [29] \\
\hline 67 & $\mathrm{O}_{2}^{-}+\mathrm{CH}_{5} \mathrm{O}^{+}<=>\mathrm{O}_{2}+\mathrm{CH}_{3}+\mathrm{H}_{2} \mathrm{O}$ & $1.00 \mathrm{E}+18$ & 0 & 0 & [29] \\
\hline 68 & $\mathrm{O}^{-}+\mathrm{C}_{2} \mathrm{H}_{3} \mathrm{O}^{+}<=>\mathrm{O}+\mathrm{CH}_{2} \mathrm{CHO}$ & $2.09 \mathrm{E}+18$ & -0.5 & 0 & [29] \\
\hline 69 & $\mathrm{O}^{-}+\mathrm{C}_{2} \mathrm{H}_{3} \mathrm{O}^{+}<=>\mathrm{O}+\mathrm{CH}_{2} \mathrm{CO}+\mathrm{H}$ & $1.00 \mathrm{E}+18$ & 0 & 0 & [29] \\
\hline 70 & $\mathrm{O}^{-}+\mathrm{C}_{2} \mathrm{H}_{3} \mathrm{O}^{+}<=>\mathrm{O}+\mathrm{CH}_{3} \mathrm{CO}$ & $1.00 \mathrm{E}+18$ & 0 & 0 & [29] \\
\hline 71 & $\mathrm{O}^{-}+\mathrm{CH}_{5} \mathrm{O}^{+}<=>\mathrm{O}+\mathrm{CH}_{3}+\mathrm{H}_{2} \mathrm{O}$ & $1.00 \mathrm{E}+18$ & 0 & 0 & [29] \\
\hline 72 & $\mathrm{CHO}_{3}{ }^{-}+\mathrm{C}_{2} \mathrm{H}_{3} \mathrm{O}^{+}<=>\mathrm{CH}_{2} \mathrm{CHO}+\mathrm{CO}_{2}+\mathrm{OH}$ & $2.00 \mathrm{E}+18$ & 0 & 0 & [29] \\
\hline 73 & $\mathrm{CHO}_{3}^{-}+\mathrm{CH}_{5} \mathrm{O}^{+}<=>\mathrm{CH}_{3} \mathrm{OH}+\mathrm{H}_{2} \mathrm{O}+\mathrm{CO}_{2}$ & $2.00 \mathrm{E}+18$ & 0 & 0 & [29] \\
\hline 74 & $\mathrm{O}_{2}+\mathrm{E}^{-}+\mathrm{O}<=>\mathrm{O}_{2}^{-}+\mathrm{O}$ & $3.63 \mathrm{E}+16$ & 0 & 0 & [29] \\
\hline 75 & $\mathrm{O}_{2}+\mathrm{E}^{-}+\mathrm{O}_{2}<=>\mathrm{O}_{2}^{-}+\mathrm{O}_{2}$ & $1.52 \mathrm{E}+21$ & -1 & 1191.9 & [29] \\
\hline 76 & $\mathrm{O}_{2}+\mathrm{E}^{-}+\mathrm{H}_{2} \mathrm{O} \Leftrightarrow=>\mathrm{O}_{2}^{-}+\mathrm{H}_{2} \mathrm{O}$ & $5.08 \mathrm{E}+18$ & 0 & 0 & [29] \\
\hline 77 & $\mathrm{O}_{2}+\mathrm{E}^{-}+\mathrm{N}_{2}<=>\mathrm{O}^{-}+\mathrm{N}_{2}$ & $3.59 E+21$ & -2 & 139 & [29] \\
\hline 78 & $\mathrm{E}^{-}+\mathrm{OH}+\mathrm{M} \Leftrightarrow=>\mathrm{OH}^{-}+\mathrm{M}$ & $1.09 \mathrm{E}+17$ & 0 & 0 & [29] \\
\hline 79 & $\mathrm{OH}^{-}+\mathrm{CO}_{2}+\mathrm{O}_{2}<=>\mathrm{CHO}_{3}^{-}+\mathrm{O}_{2}$ & $2.76 \mathrm{E}+20$ & 0 & 0 & [29] \\
\hline 80 & $\mathrm{OH}^{-}+\mathrm{CO}_{2}+\mathrm{H}_{2} \mathrm{O} \Leftrightarrow=>\mathrm{CHO}_{3}^{-}+\mathrm{H}_{2} \mathrm{O}$ & $1.10 \mathrm{E}+21$ & 0 & 0 & [29] \\
\hline 81 & $\mathrm{E}^{-}+\mathrm{O}+\mathrm{O}_{2}<=>\mathrm{O}^{-}+\mathrm{O}_{2}$ & $3.63 \mathrm{E}+16$ & 0 & 0 & [29] \\
\hline 82 & $\mathrm{E}^{-}+\mathrm{O}+\mathrm{O}<=>\mathrm{O}^{-}+\mathrm{O}$ & $3.02 E+17$ & 0 & 0 & [29] \\
\hline 83 & $\mathrm{O}^{-}+\mathrm{CO}_{2}+\mathrm{O}_{2}<=>\mathrm{CO}_{3}^{-}+\mathrm{O}_{2}$ & $1.12 \mathrm{E}+20$ & 0 & 0 & [29] \\
\hline 84 & $\mathrm{CO}_{3}{ }^{-}+\mathrm{OH}=>\mathrm{CO}_{2}+\mathrm{HO}_{2}+\mathrm{E}^{-}$ & $3.55 E+15$ & -0.25 & 0 & [29] \\
\hline 85 & $\mathrm{CHO}_{3}^{-}+\mathrm{OH}<=>\mathrm{CO}_{3}^{-}+\mathrm{H}_{2} \mathrm{O}$ & $3.50 \mathrm{E}+15$ & -0.25 & 0 & [29] \\
\hline
\end{tabular}

a: E- represents electron.

b: $\mathrm{CH}^{*}$ is written as $\mathrm{CHV}$ in kinetic file.

A detailed quantum chemistry calculation method was employed to calculate thermodynamic properties of ions. Radicals and their corresponding cations were optimized with Becke-3parameter [32] Lee-Young-Parr [33]/6-31+G(d,p) level of calculation and then the total energies are determined with CBS-QB3 [34] and CBS-APNO [35] composite calculations. All calculations were performed using the Gaussian 09 [36] suite of program. Standard enthalpies of formation of cations were derived from the cations and their derived radicals. The average values of enthalpy of formation which was calculated with CBS-QB3 and CBS-APNO were recommended as the standard enthalpy of formation of target species. Detailed geometry information for each species and standard enthalpy of formation compared against available literature [37] can be found in Supplementary Material-2. Entropy and heat capacity contributions as a function of temperature were determined from the calculated structure, moments of inertia, vibrational frequencies, 
symmetry, electron degeneracy, number of optical isomers, and the known mass of each species. SMCPS [38] program was applied to calculate the contributions of translation, external rotation, and vibrations by using standard formulas from statistical mechanics. Vibrational frequencies were scaled by a factor of 0.964 [39] for calculation of standard entropy and heat capacity at the B3LYP/6-31+G(d,p) level of calculation. Rotator program [40] was used to calculate the contribution from the corresponding internal rotor torsion frequencies. In this work, a tenparameter Fourier series function was presented as a torsional potential curve to calculate the contribution of free internal rotation. All values reported are for a standard state of $298 \mathrm{~K}$ and 1 atm. Ion transport parameters were estimated according to a mixture-averaged approach, and electron mobility was set as $0.4 \mathrm{~m}^{2} \mathrm{~V}^{-1} \mathrm{~s}^{-1}$ [41]. The ion chemistry mechanism files are available in Supplementary Material-3.

\subsubsection{Temperature profiles}

For flame A, B and C, temperature profiles used for simulation were measured and corrected by B-type thermocouple. Sampling cone cooling effect and perturbations were assumed to be negligible because the metallic cone used for cation measurements is small. For flame $\mathrm{D}$, a large quartz sampling cone was used for neutral measurements, so cooling effects of the sampling cone were considered. Sampling-cone-perturbed temperature profiles were calculated using the proportionality between the temperature and first stage pressure behind the sampling cone [42], as described in Eq. (1):

$p_{1 s t}=c \cdot \sqrt{\frac{\gamma}{\bar{M} T}} \cdot\left(\frac{2}{\gamma+1}\right)^{Z}$

$p_{1 s t}$ is the first stage pressure behind the sampling cone; $\mathrm{c}$ as machine constant; $\Upsilon$ as the specific heat $\left(c_{p} / c_{v}\right) ; \bar{M}$ as average molecular weight; $\mathrm{T}$ as local temperature, and $\mathrm{z}=(\Upsilon+1) / 2(\Upsilon$ - 
2). $p_{1 s t}$ is recorded with the change of $\mathrm{HAB}$ experimentally. The proportionality constant $\mathrm{c}$ was obtained by measured temperature at $\mathrm{HAB}=30 \mathrm{~mm}$ using the aforementioned B-type thermocouple. Once $\bar{M}, \mathrm{z}$ and $\mathrm{c}$ are determined, temperature profiles were calculated by Eq. (1).

\subsubsection{Simulation software and conditions}

Low pressure flames were simulated as one-dimensional premixed flat flames with PREMIX code in Chemkin Pro software [43]. For flame A, B and C, temperature profiles used for simulation were provided by B-type thermocouple measurements with radiation corrections. For flame D, the temperature profiles used for simulation were calculated from first stage pressure to account for cooling effect on the sampling cone. Two modifications were implemented in the code to account for transport of charged species as in previous work. Electric potential was added as an additional variable and the Poisson equation was solved. Drift diffusion flux was included in the charged species flux [41]. The simulation conditions are as follows: gradient 0.1 , curvature 0.1 , initial number of grid points 22, mixture-averaged transport, and with fixed temperature profiles. Thermal diffusion (Soret effect) was not accounted for.

\section{Results and discussions}

\subsection{Cations identification}

Cations with high signal to noise ratio $(>10)$ at different nominal mass are presented in Table 3. Other cations with low signal to noise ratio are below the experimental detection limit, so are not presented. To identify cation formula and isomer structure for each nominal mass signal, two methods were employed. The first method compares detected cation signals with those in literature $[1,8,13,16]$. For example, signals detected at $\mathrm{m} / \mathrm{z}=43$ correspond to three possible chemical formula: $\mathrm{C}_{2} \mathrm{H}^{+} \cdot \mathrm{H}_{2} \mathrm{O}, \mathrm{C}_{2} \mathrm{H}_{3} \mathrm{O}^{+}$and $\mathrm{C}_{3} \mathrm{H}_{7}{ }^{+}$. The chemical formula at $\mathrm{m} / \mathrm{z}=43$ could be $\mathrm{C}_{2} \mathrm{H}_{3} \mathrm{O}^{+}$as 
suggested by high resolution TOF-MS data in [16]. However, $\mathrm{C}_{2} \mathrm{H}_{3} \mathrm{O}^{+}$can still have eight isomers. To further narrow-down the possible options and identify dominant isomer structures, a second method employed quantum chemistry calculations of all isomers thermodynamic properties. The calculated results are listed in Table 4. The $\mathrm{C}_{2} \mathrm{H}_{3} \mathrm{O}^{+}$isomer with lowest enthalpy at $2000 \mathrm{~K}$ is assumed to be the dominant one, and thus $\mathrm{C}_{2} \mathrm{H}_{3} \mathrm{O}^{+}$is designated as the protonated ketene. Following similar methodology, thermodynamic calculation results of five isomers of $\mathrm{C}_{3} \mathrm{H}_{3}{ }^{+}$are listed in Table 5, and the dominant isomer structure is the protonated propargyl. Other cation thermodynamic calculation results are included in Supplementary Material-2. The final list of identified cations is in Table 3.

Table 3 Dominant cation formula and isomer structure for each detectable nominal mass signal. Bold ones are considered as key cations for each nominal mass. A: dominant isomers determined by quantum chemistry calculation in this work.

\begin{tabular}{|c|c|c|c|c|c|}
\hline $\mathrm{m} / \mathrm{z}$ & \multicolumn{3}{|c|}{ Possible Ion Formula } & Dominant cation structures & Ref \\
\hline 19 & $\mathrm{H}_{3} \mathrm{O}^{+}$ & & & & [1] \\
\hline 37 & $\mathrm{H}_{3} \mathrm{O}^{+} \bullet \mathrm{H}_{2} \mathrm{O}$ & $\mathrm{C}_{3} \mathrm{H}^{+}$ & & & [1] \\
\hline 39 & $\mathrm{C}_{3} \mathrm{H}_{3}{ }^{+}$ & $\mathrm{CH}_{5}{ }^{+} \bullet \mathrm{H}_{2} \mathrm{O}$ & & & A \\
\hline 41 & $\mathrm{HCCO}^{+}$ & $\mathrm{C}_{3} \mathrm{H}_{5}^{+}$ & & $\mathrm{H}-\mathrm{C} \equiv \mathrm{O}$ & A \\
\hline 43 & $\mathrm{C}_{2} \mathrm{H}_{3} \mathrm{O}^{+}$ & $\mathrm{C}_{2} \mathrm{H}^{+} \bullet \mathrm{H}_{2} \mathrm{O}$ & $\mathrm{C}_{3} \mathrm{H}_{7}^{+}$ & & $A$ \\
\hline 51 & $\mathrm{CH}_{5} \mathrm{O}^{+} \bullet \mathrm{H}_{2} \mathrm{O}$ & $\mathrm{C}_{4} \mathrm{H}_{3}{ }^{+}$ & $\mathrm{CH}_{3}+\bullet 2 \mathrm{H}_{2} \mathrm{O}$ & & [8] \\
\hline
\end{tabular}




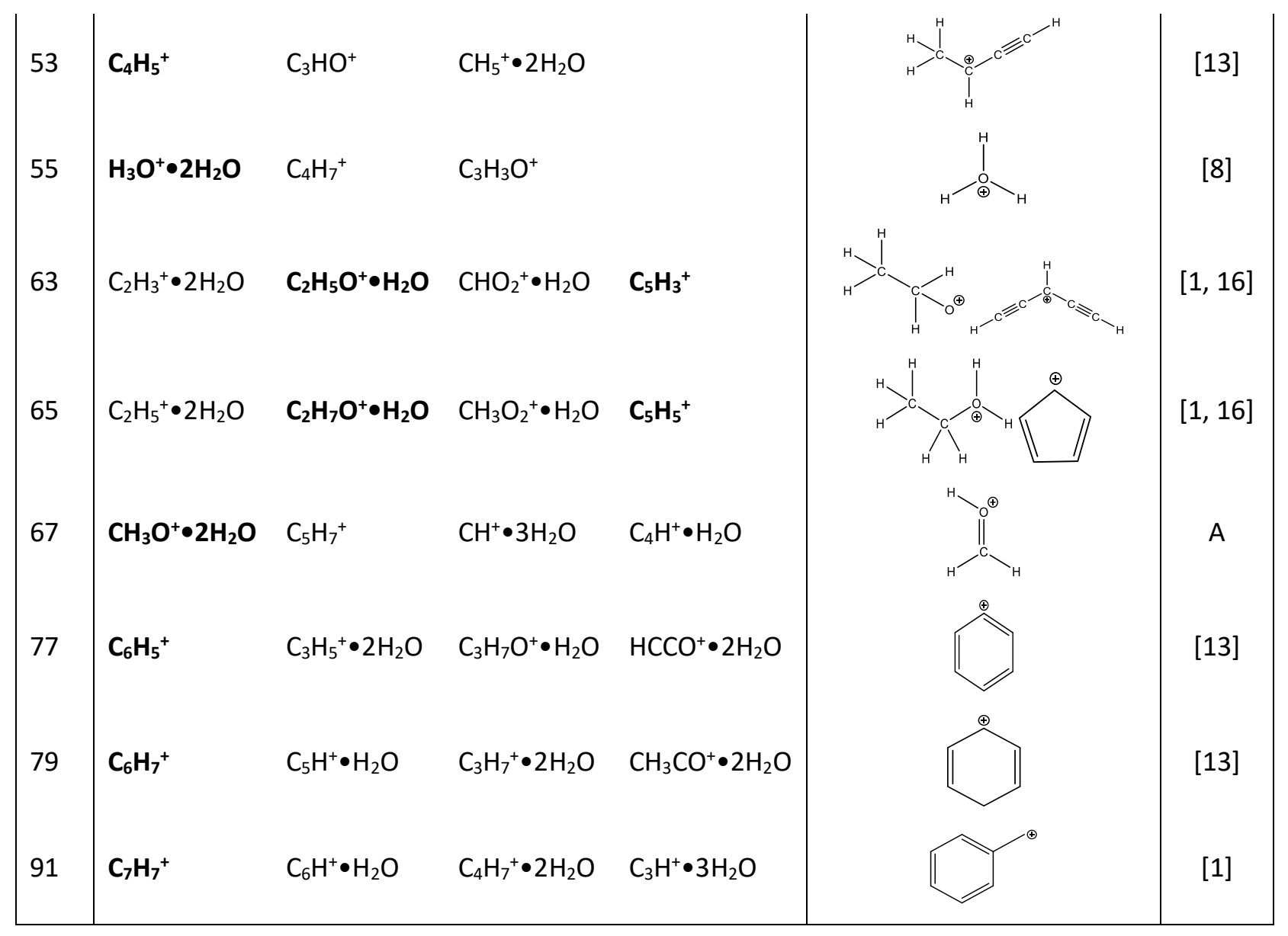

Table 4 Calculated thermodynamic properties of all possible $\mathrm{C}_{2} \mathrm{H}_{3} \mathrm{O}^{+}$isomers at $2000 \mathrm{~K}$

\begin{tabular}{|c|c|c|c|c|c|}
\hline Formula & Name & Structure & $\mathrm{H}(\mathrm{kcal} / \mathrm{mol})$ & $\mathrm{S}(\mathrm{cal} / \mathrm{mol} / \mathrm{K})$ & $\mathrm{Cp}(\mathrm{cal} / \mathrm{mol} / \mathrm{K})$ \\
\hline $\mathrm{C} 2 \mathrm{H} 3 \mathrm{O}$ & CCJDO & & 333.82 & 106.88 & 29.44 \\
\hline & $\mathrm{CDCJOH}$ & & 257.16 & 103.66 & 28.83 \\
\hline & CDCOJ & & 280.64 & 104.34 & 29.06 \\
\hline & CJCDO & & 280.64 & 104.33 & 29.06 \\
\hline & $\mathrm{CJDCOH}$ & & 258.19 & 103.31 & 28.84 \\
\hline
\end{tabular}




\begin{tabular}{lllll} 
YCJCO & 304.54 & 104.85 & 29.37 \\
YCDCOH & & & 28.78 \\
CDCDOH & & 102.14 & $\mathbf{2 8 . 7 8}$ \\
\hline
\end{tabular}

Table 5 Calculated thermodynamic properties of all possible $\mathrm{C}_{3} \mathrm{H}_{3}{ }^{+}$isomers at $2000 \mathrm{~K}$

\begin{tabular}{|c|c|c|c|c|c|}
\hline Formula & Name & Structure & $\mathrm{H}(\mathrm{kcal} / \mathrm{mol})$ & $\mathrm{S}(\mathrm{cal} / \mathrm{mol} / \mathrm{K})$ & $\mathrm{Cp}(\mathrm{cal} / \mathrm{mol} / \mathrm{K})$ \\
\hline $\mathrm{C} 3 \mathrm{H} 3$ & CJDCDC & & 285.71 & 106.74 & 29.20 \\
\hline & CCTCJ & & 284.34 & 105.30 & 29.11 \\
\hline & YCDCCJ & & 300.19 & 101.00 & 29.27 \\
\hline & CTCCJ & & 286.31 & 106.66 & 29.19 \\
\hline & YCJDCC & & 399.97 & 103.14 & 29.22 \\
\hline
\end{tabular}

\subsection{Experimental observation of cation distribution}

Cation and temperature profiles in flames $\mathrm{A}, \mathrm{B}$ and $\mathrm{C}$ were measured after cation identification. The results of major cations $\left(\mathrm{H}_{3} \mathrm{O}^{+}\right.$and $\left.\mathrm{C}_{3} \mathrm{H}_{3}{ }^{+}\right)$, minor cations, and temperature profiles are presented in Figure 1 and 2. Measured cation profiles are shifted away from the burner in flame A, B and C by 2, 4 and $5 \mathrm{~mm}$, respectively. The shift is due to sampling cone disturbance [23], and the shift distance for each flame is determined by comparison between major species $\left(\mathrm{CH}_{4}, \mathrm{O}_{2}, \mathrm{CO}\right.$ and $\left.\mathrm{CO}_{2}\right)$ measured and simulated profiles. Major species measured profiles were obtained with electron ionization in quadrupole MBMS at $20 \mathrm{eV}$, and their simulated profiles were 
calculated with thermocouple measured temperature profiles. Detailed shift distance determination is presented in Figure S4 and discussed in Supplementary Material-1. Two major cations, namely $\mathrm{H}_{3} \mathrm{O}^{+}$and $\mathrm{C}_{3} \mathrm{H}_{3}{ }^{+}$, account for over $80 \%$ of total cation signals, as observed in many hydrocarbon non-sooting flames, e.g. methane flames [8], ethylene flames [5], acetylene flames [44] and propane flames [15]. Experimentally, the change of dominant cation with equivalence ratio is captured. In slightly rich flame A $(\phi=1.5), \mathrm{H}_{3} \mathrm{O}^{+}$is the dominant cation, but in richer flames B $(\phi=1.8)$ and $\mathrm{C}(\phi=2.0)$, the dominant cation changes to $\mathrm{C}_{3} \mathrm{H}_{3}{ }^{+}$. Similar observations are found in acetylene flames $[31,44]$. To explain this phenomenon, numerical simulation are presented in the next section.
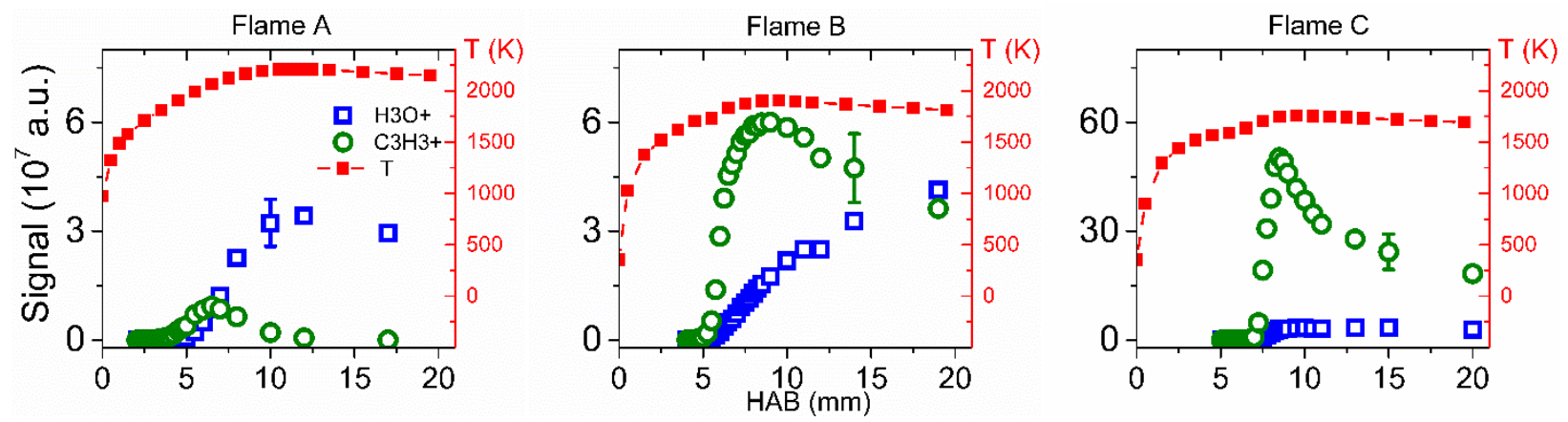

Figure 1 Major cation profiles and temperature profiles versus height above burner in flame A, B and C. Cation profiles in flame A, B and C are shifted away from the burner by 2, 4 and $5 \mathrm{~mm}$. Cation measurement error is reported as $20 \%$.

Besides $\mathrm{H}_{3} \mathrm{O}^{+}$and $\mathrm{C}_{3} \mathrm{H}_{3}{ }^{+}$, thirteen minor cations are detected, identified, and presented in Figure 2. They can be classified into two groups: oxygenated cations and hydrocarbon cations. $\mathrm{C}_{2} \mathrm{H}_{3} \mathrm{O}^{+}, \mathrm{HCCO}^{+}, \mathrm{CH}_{3} \mathrm{O}^{+}, \mathrm{CH}_{5} \mathrm{O}^{+}, \mathrm{C}_{2} \mathrm{H}_{5} \mathrm{O}^{+}$and $\mathrm{C}_{2} \mathrm{H}_{7} \mathrm{O}^{+}$fall into the first group; $\mathrm{C}_{3} \mathrm{H}_{5}{ }^{+}, \mathrm{C}_{4} \mathrm{H}_{5}{ }^{+}$, $\mathrm{C}_{5} \mathrm{H}_{3}{ }^{+}, \mathrm{C}_{5} \mathrm{H}_{5}{ }^{+}, \mathrm{C}_{6} \mathrm{H}_{5}+, \mathrm{C}_{6} \mathrm{H}_{7}{ }^{+}$and $\mathrm{C}_{7} \mathrm{H}_{7}{ }^{+}$are in the second group. For signals at $\mathrm{m} / \mathrm{z}=41,63$ and 65 , both oxygenated cations $\left(\mathrm{HCCO}^{+}, \mathrm{C}_{2} \mathrm{H}_{5} \mathrm{O}^{+} \cdot \mathrm{H}_{2} \mathrm{O}\right.$ and $\left.\mathrm{C}_{2} \mathrm{H}_{7} \mathrm{O}^{+} \cdot \mathrm{H}_{2} \mathrm{O}\right)$ and hydrocarbon cations 
$\left(\mathrm{C}_{3} \mathrm{H}_{5}{ }^{+}, \mathrm{C}_{5} \mathrm{H}_{3}{ }^{+}\right.$and $\left.\mathrm{C}_{5} \mathrm{H}_{5}{ }^{+}\right)$are possible and inseparable, so their signals are added and presented together. For some cation profiles, e.g. $\mathrm{m} / \mathrm{z}=65$, there is an initial value in the early profile. The reason why some cation profiles do not start near zero may be due to sampling cone perturbation effects at the burner surface. With increasing equivalence ratio, hydrocarbon cations contribute more to the total signal compared to oxygenated cations. This is expected because an increase of equivalence ratio reduces oxygen, so fewer oxygenated cations are produced. The minor cations measured here have been found in other hydrocarbon flames, e.g. ethylene, acetylene, propane and butane flames [1]. We hypothesize that ion chemistry is similar in flames fueled by different hydrocarbons. 

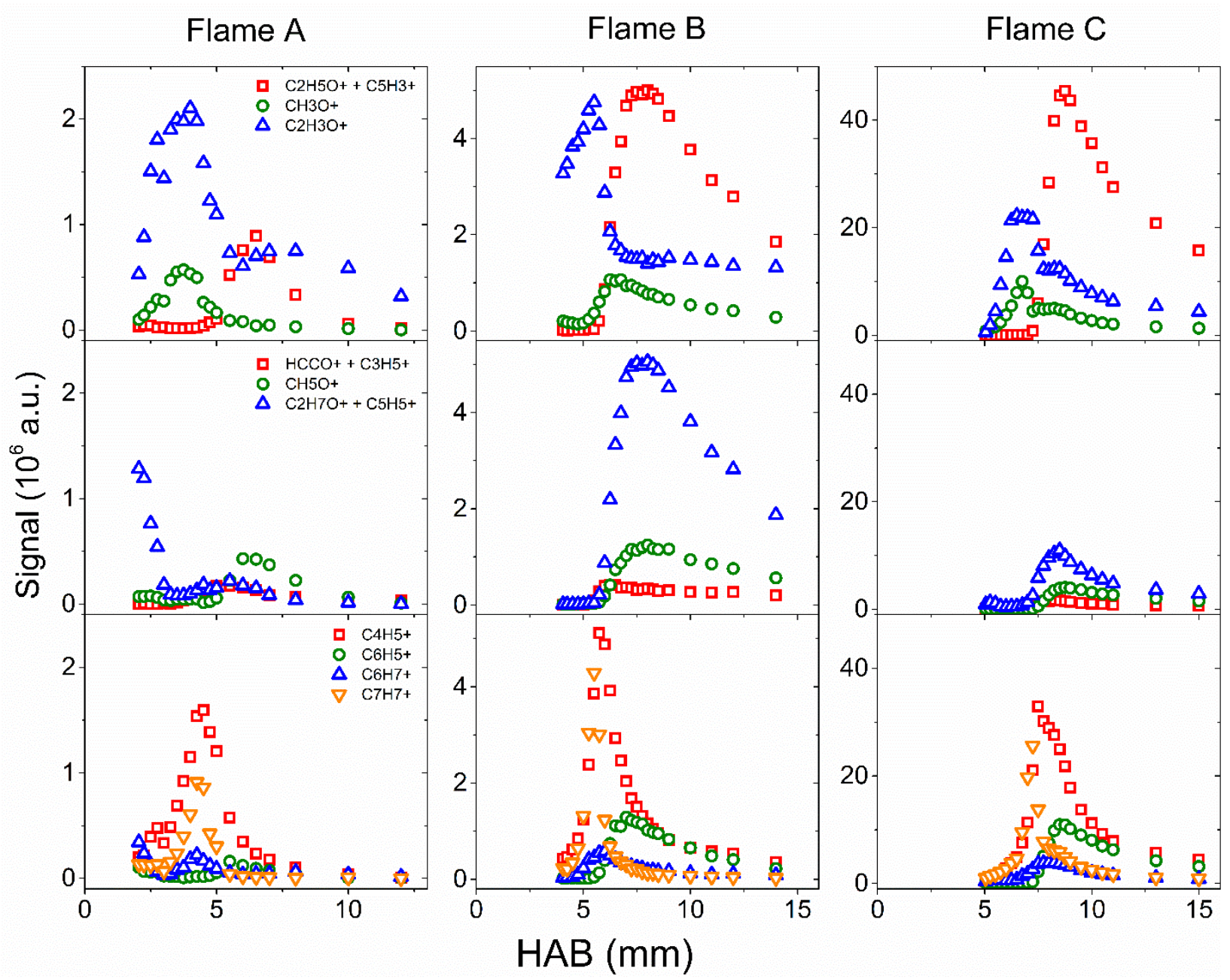

Figure 2 Minor cation profiles versus height above burner in flames A, B and C. Cation profiles in flames A, B and C are shifted away from the burner by 2, 4 and $5 \mathrm{~mm}$, respectively.

\subsection{Predictions for dominant cations $\mathrm{H}_{3} \mathrm{O}^{+}$and $\mathrm{C}_{3} \mathrm{H}_{3}{ }^{+}$}

To explain the change of dominant cations with equivalence ratios, numerical simulations are presented in this section. $\mathrm{H}_{3} \mathrm{O}^{+}$and $\mathrm{C}_{3} \mathrm{H}_{3}{ }^{+}$profiles were simulated using the proposed mechanism and reported temperature profiles in flames A, B and C. The results appear in Figure 3. The overall cation mole fraction decreases with increasing equivalence ratio, which can be expected due to the lower temperature in richer flames. Numerical simulations successfully capture the change of 
dominant cations in the flames. $\mathrm{H}_{3} \mathrm{O}^{+}$is predicted as the dominant cation in flame $\mathrm{A}(\phi=1.5)$ while $\mathrm{C}_{3} \mathrm{H}_{3}{ }^{+}$dominates cation distribution pool in richer flame $\mathrm{B}(\phi=1.8)$ and $\mathrm{C}(\phi=2.0)$. One more observation is that numerical predictions are very sensitive to flame temperatures under different equivalence ratios. Predicted major cation concentrations in three flames exhibit two order of magnitude difference between flames A and C, while experimental measurements in Fig 1 showed similar signal intensities in all Flames. Since most of ion-neutral reactions are insensitive to temperature, activation energies of sensitive cation chemi-ionization reactions need further examination.
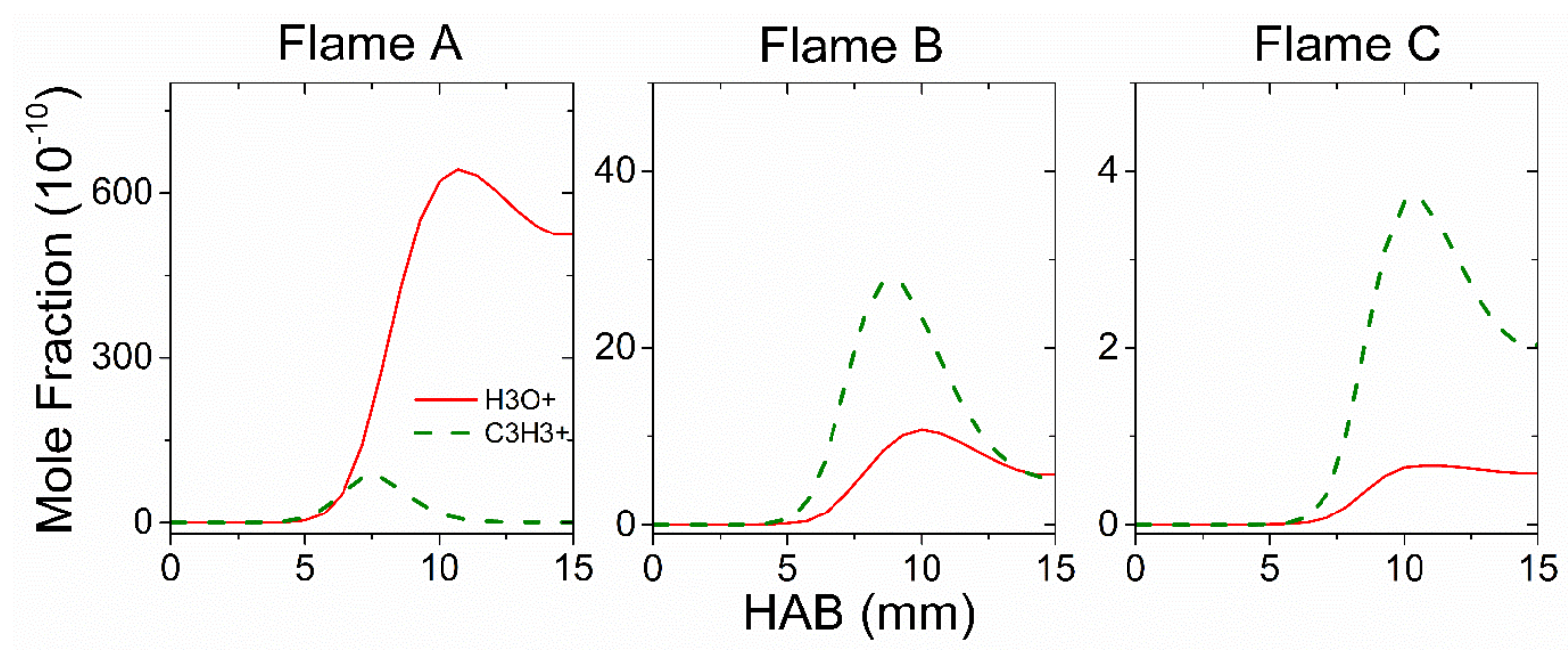

Figure 3 Simulated $\mathrm{H}_{3} \mathrm{O}^{+}$and $\mathrm{C}_{3} \mathrm{H}_{3}{ }^{+}$profiles in flames A, B and C.

Different chemi-ionization reactions could be responsible for the change of dominant cations with varying equivalence ratio. Two possible chemi-ionization reactions (reaction index are listed in Table 2) proposed in hydrocarbon flames $[9,10,12]$ are:

$$
\begin{aligned}
& \mathrm{CH}+\mathrm{O}<->\mathrm{CHO}^{+}+\mathrm{e}^{-} \\
& \mathrm{CH}^{*}+\mathrm{C}_{2} \mathrm{H}_{2}<->\mathrm{C}_{3} \mathrm{H}_{3}^{+}+\mathrm{e}^{-}
\end{aligned}
$$


These two chemi-ionization reactions are competing reactions. When $\mathrm{O}$ is abundant, e.g. lean, stoichiometric and slight-rich flames, reaction (1) is the dominant reaction $[6,18]$. But when $\mathrm{C}_{2} \mathrm{H}_{2}$ is abundant, e.g. sooting flames and rich acetylene flames, reaction (20) becomes the dominant reactions $[12,13]$. In the very rich flame $\mathrm{C}, \mathrm{C}_{3} \mathrm{H}_{3}{ }^{+}$signal accounts for over $90 \%$ of total cation signals, so reaction (20) is assumed to be the main chemi-ionization reaction because of large $\mathrm{C}_{2} \mathrm{H}_{2}$ concentration and low $\mathrm{O}$ concentration. As equivalence ratio drops from 2.0 to 1.8 in flame $\mathrm{B}$, reaction (1) and (20) would both serve as chemi-ionization reactions while $\mathrm{C}_{3} \mathrm{H}_{3}{ }^{+}$retains its dominance. When equivalence ratio drops to 1.5 in flame $\mathrm{A}, \mathrm{H}_{3} \mathrm{O}^{+}$becomes the most dominant cation, and reaction (1) would be main chemi-ionization reaction with the increasing concentration of $\mathrm{O}$. The change of dominant cation implies that the dominant chemi-ionization reaction changes between reaction (1) and reaction (20) under different equivalence ratios. When $\mathrm{C}_{3} \mathrm{H}_{3}{ }^{+}$is the major cation, dominant chemi-ionization reaction is reaction (20), and when $\mathrm{H}_{3} \mathrm{O}^{+}$is dominant, it would be reaction (1).

Reaction (19) may also be an important chemi-ionization reaction. However, current kinetic models use a very high activation energy for reaction (19), which makes the rate constant much smaller than reaction (1) and (20). Uncertainty in the activation energy of reaction (19) may contribute to the discrepancy between simulated cation concentrations in three flames compared to experiments.

\subsection{Ion-neutral reaction pathways}

To reveal and verify ion-neutral reaction network in ion chemistry, neutrals in flame D were measured by SVUV-PI-TOF-MBMS. Twenty three neutrals were first identified by their mass and photo ionization energies, and then measured and quantified by MBMS. Mass and photo ionization 
energies of measured neutrals are listed in Table S3 in Supplementary Material-1, and detailed experimental data is included in Supplementary Material-4. Original cation profiles in flame D are obtained by quadrupole MBMS from previous work [16]. Comparisons among numerical simulations, quadrupole MBMS and SVUV-PI-TOF-MBMS measurements for major species profiles $\left(\mathrm{CH}_{4}, \mathrm{O}_{2}, \mathrm{CO}\right.$ and $\left.\mathrm{CO}_{2}\right)$ show good agreement in Figure 4 and Figure S5 in Supplementary Material-1, which can validate the accuracy and uniformity between two experiments.

After examination of two MBMS measurements, cation profiles are plotted with neutral profiles to elucidate the ion chemistry reaction network. $\mathrm{H}_{3} \mathrm{O}^{+}$is compared with $\mathrm{H}_{2} \mathrm{O}$ and $\mathrm{CO}$; $\mathrm{C}_{3} \mathrm{H}_{3}{ }^{+}$with $\mathrm{C}_{2} \mathrm{H}_{2} ; \mathrm{C}_{2} \mathrm{H}_{3} \mathrm{O}^{+}$with $\mathrm{CH}_{2} \mathrm{CO} ; \mathrm{C}_{2} \mathrm{H}_{5} \mathrm{O}^{+}$with $\mathrm{CH}_{3} \mathrm{CHO}$ and $\mathrm{C}_{2} \mathrm{H}_{3} \mathrm{OH} ; \mathrm{CH}_{5} \mathrm{O}^{+}$with $\mathrm{CH}_{3} \mathrm{OH} ; \mathrm{CH}_{3} \mathrm{O}^{+}$with $\mathrm{CH}_{2} \mathrm{O}$; and $\mathrm{C}_{4} \mathrm{H}_{5}{ }^{+}$with $\mathrm{C}_{3} \mathrm{H}_{4}-\mathrm{A}, \mathrm{C}_{3} \mathrm{H}_{4}-\mathrm{P}$ and $\mathrm{C}_{4} \mathrm{H}_{4}$. Comparison among cation profiles and neutral profiles helps to examine ion-neutral reaction pathways.

\subsection{1 $\mathrm{H}_{3} \mathrm{O}^{+}$}

The most abundant cation in flame $\mathrm{D}$ is $\mathrm{H}_{3} \mathrm{O}^{+}$, which accounts for over $60 \%$ of the total cation signal. $\mathrm{H}_{3} \mathrm{O}^{+}$is produced mainly through $\mathrm{CHO}^{+}$proton transfer reaction after chemi-ionization reaction (1) $[6,18]$ :

$\mathrm{CH}+\mathrm{O}<->\mathrm{CHO}^{+}+\mathrm{E}^{-}$

$\mathrm{CHO}^{+}+\mathrm{H}_{2} \mathrm{O}<->\mathrm{H}_{3} \mathrm{O}^{+}+\mathrm{CO}$

To verify reaction (2) as the dominant $\mathrm{H}_{3} \mathrm{O}^{+}$production pathway, $\mathrm{H}_{2} \mathrm{O}$ and $\mathrm{CO}$ profiles are compared with $\mathrm{H}_{3} \mathrm{O}^{+}$profiles in Figure 4. Measured $\mathrm{H}_{3} \mathrm{O}^{+}$signals were scaled to fit numerical simulations. The correlation between $\mathrm{H}_{3} \mathrm{O}^{+}$and $\mathrm{H}_{2} \mathrm{O}$ profiles proves that reaction (2) could be the dominant pathway for $\mathrm{H}_{3} \mathrm{O}^{+}$production. 
The consumption reactions for $\mathrm{H}_{3} \mathrm{O}^{+}$may be propagation reactions in the flame zone and recombination reactions [18]:

$\mathrm{H}_{3} \mathrm{O}^{+}+\mathrm{C}_{2} \mathrm{H}_{2}<->\mathrm{C}_{2} \mathrm{H}_{3} \mathrm{O}^{+}+\mathrm{H}_{2}$

$\mathrm{H}_{3} \mathrm{O}^{+}+\mathrm{E}^{-}<->$products

In post flame zone of flame $\mathrm{D}$, reactions (3)-(7) would be important because $\mathrm{H}_{3} \mathrm{O}^{+}$is the only cation which remains in large amounts. Its decay rate could be utilized to assess recombination reaction rates. The slow decay of simulated $\mathrm{H}_{3} \mathrm{O}^{+}$profile in Figure 4 indicates $\mathrm{H}_{3} \mathrm{O}^{+}$recombination rates are over-estimated. In very rich flames, e.g. flame $\mathrm{C}, \mathrm{H}_{3} \mathrm{O}^{+}$recombination reactions are less important since the dominant cation in post flame zone changes to $\mathrm{C}_{3} \mathrm{H}_{3}{ }^{+}$.
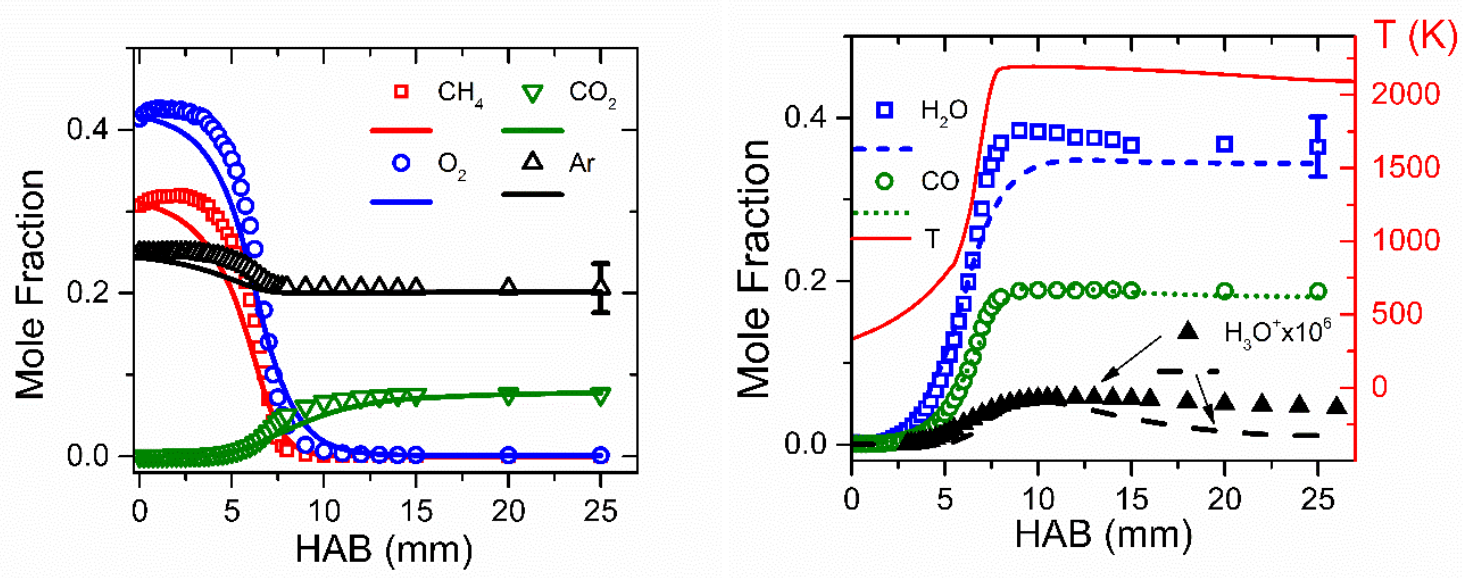

Figure 4 Species profiles $\left(\mathrm{CH}_{4}, \mathrm{O}_{2}, \mathrm{Ar}, \mathrm{H}_{2} \mathrm{O}, \mathrm{CO}\right.$ and $\left.\mathrm{H}_{3} \mathrm{O}^{+}\right)$and temperature profiles in flame D. Scatter points are experimental data while lines are numerical predictions. Error bars show $15 \%$ experimental uncertainty for major species. $\mathrm{H}_{3} \mathrm{O}^{+}$mole fraction profiles are scaled from measured signals to fit numerical simulations, and multiplied by $10^{6}$ both experimentally and numerically for better comparison. 


\subsection{2 $\mathrm{C}_{3} \mathrm{H}_{3}^{+}$}

The second most abundant and important cation in flame $\mathrm{D}$ is $\mathrm{C}_{3} \mathrm{H}_{3}{ }^{+}$. The key production pathway for $\mathrm{C}_{3} \mathrm{H}_{3}{ }^{+}$could be chemi-ionization reaction as aforementioned or the condensationelimination reaction [31]:

$\mathrm{CH}_{3}{ }^{+}+\mathrm{C}_{2} \mathrm{H}_{2}<->\mathrm{C}_{3} \mathrm{H}_{3}{ }^{+}+\mathrm{H}_{2}$

And $\mathrm{CH}_{3}{ }^{+}$could be produced through proton transfer reactions [31]:

$$
\begin{aligned}
& \mathrm{CHO}^{+}+\mathrm{CH}_{2}<->\mathrm{CH}_{3}{ }^{+}+\mathrm{CO} \\
& \mathrm{H}_{3} \mathrm{O}^{+}+\mathrm{CH}_{2}<->\mathrm{CH}_{3}{ }^{+}+\mathrm{H}_{2} \mathrm{O}
\end{aligned}
$$

To examine reaction (30) as the main $\mathrm{C}_{3} \mathrm{H}_{3}{ }^{+}$production pathway, $\mathrm{C}_{3} \mathrm{H}_{3}{ }^{+}$and $\mathrm{C}_{2} \mathrm{H}_{2}$ profiles are compared in Figure $5 . \mathrm{C}_{3} \mathrm{H}_{3}{ }^{+}$mole fraction profiles were obtained by scaling measured signals with same scaling factor as $\mathrm{H}_{3} \mathrm{O}^{+}$. If reaction (20) is dominant, $\mathrm{C}_{2} \mathrm{H}_{2}$ and $\mathrm{C}_{3} \mathrm{H}_{3}{ }^{+}$would have the same peak location; on the other hand, if reaction (30) is dominant, $\mathrm{C}_{2} \mathrm{H}_{2}$ would peak earlier than $\mathrm{C}_{3} \mathrm{H}_{3}{ }^{+}$since reaction (30) consumes $\mathrm{C}_{2} \mathrm{H}_{2}$ and produces $\mathrm{C}_{3} \mathrm{H}_{3}{ }^{+}$. Experimental observations show that $\mathrm{C}_{2} \mathrm{H}_{2}$ peaks earlier than $\mathrm{C}_{3} \mathrm{H}_{3}{ }^{+}$, suggesting reaction (30) could be the main production pathway for $\mathrm{C}_{3} \mathrm{H}_{3}{ }^{+}$. Simulated $\mathrm{C}_{2} \mathrm{H}_{2}$ and $\mathrm{C}_{3} \mathrm{H}_{3}{ }^{+}$have the same peak location indicating that reaction (20) is the main initiation reaction. This contradicts experimental observations, suggesting that further investigation on these two reactions is required. Another reason why reaction (30) could be dominant is because the other reactant, $\mathrm{CH}_{3}{ }^{+}$, is in much higher concentrations than the other reactant, $\mathrm{CH}^{*}$, in reaction 20.

In the post-flame zone, the consumption pathways for $\mathrm{C}_{3} \mathrm{H}_{3}{ }^{+}$could be attributed to ion-neutral reaction and recombination reactions [30]: 
$\mathrm{C}_{3} \mathrm{H}_{3}{ }^{+}+\mathrm{H}_{2} \mathrm{O}<->\mathrm{C}_{2} \mathrm{H}_{3} \mathrm{O}^{+}+\mathrm{CH}_{2}$

$\mathrm{C}_{3} \mathrm{H}_{3}{ }^{+}+\mathrm{E}^{-}<->\mathrm{C}_{3} \mathrm{H}_{2}+\mathrm{H}$

In slightly-rich flames $\mathrm{A}$ and $\mathrm{D}$, the major consumption reaction pathway would be reaction (31) due to the fast decay of $\mathrm{C}_{3} \mathrm{H}_{3}{ }^{+}$in the flame zone. But in very rich flames $\mathrm{B}$ and $\mathrm{C}$, the slow decay of $\mathrm{C}_{3} \mathrm{H}_{3}{ }^{+}$profiles favors reaction (29) as the key consumption reaction, replacing reactions (3)-(7) as the dominant recombination reaction in post flame zone.

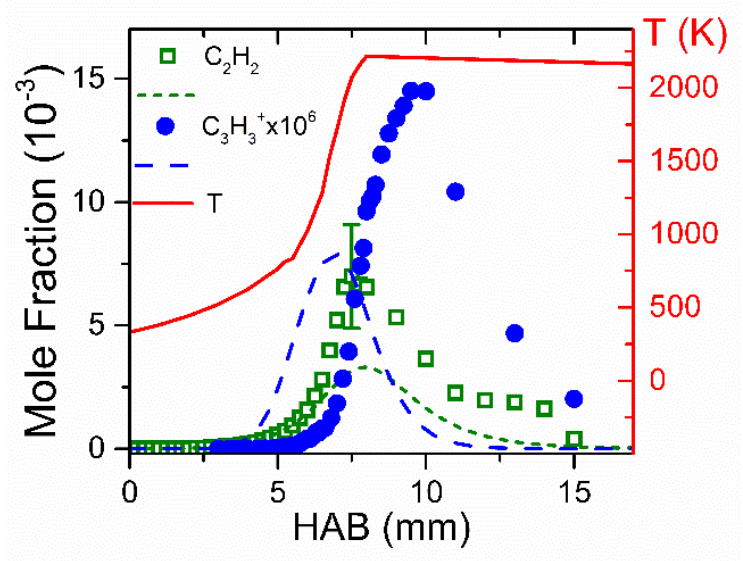

Figure $5 \mathrm{C}_{3} \mathrm{H}_{3}{ }^{+}, \mathrm{C}_{2} \mathrm{H}_{2}$ and temperature profiles in flame D. Scatter points are experimental data while lines are numerical predictions. Error bars show 30\% experimental uncertainty for $\mathrm{C}_{2} \mathrm{H}_{2}$. $\mathrm{C}_{3} \mathrm{H}_{3}{ }^{+}$mole fraction profiles are scaled from measured signals with same scaling factor as $\mathrm{H}_{3} \mathrm{O}^{+}$, and amplified by $10^{6}$ both experimentally and numerically for better comparison.

\subsubsection{Oxygenated cations}

For oxygenated cations, proton transfer reactions proceed easily because the electronegative oxygen in parent neutrals can easily abstract hydrogen ion and form oxygenated cations. Therefore, production pathways for $\mathrm{C}_{2} \mathrm{H}_{3} \mathrm{O}^{+}, \mathrm{C}_{2} \mathrm{H}_{5} \mathrm{O}^{+}, \mathrm{CH}_{3} \mathrm{O}^{+}$and $\mathrm{CH}_{5} \mathrm{O}^{+}$could be proton transfer reactions [18]: 
$\mathrm{H}_{3} \mathrm{O}^{+}+\mathrm{CH}_{2} \mathrm{CO}<->\mathrm{C}_{2} \mathrm{H}_{3} \mathrm{O}^{+}+\mathrm{H}_{2} \mathrm{O}$

$\mathrm{H}_{3} \mathrm{O}^{+}+\mathrm{C}_{2} \mathrm{H}_{4} \mathrm{O}<->\mathrm{C}_{2} \mathrm{H}_{5} \mathrm{O}^{+}+\mathrm{H}_{2} \mathrm{O}$

$\mathrm{H}_{3} \mathrm{O}^{+}+\mathrm{CH}_{2} \mathrm{O}<->\mathrm{CH}_{3} \mathrm{O}^{+}+\mathrm{H}_{2} \mathrm{O}$

$\mathrm{H}_{3} \mathrm{O}^{+}+\mathrm{CH}_{3} \mathrm{OH}<->\mathrm{CH}_{5} \mathrm{O}^{+}+\mathrm{H}_{2} \mathrm{O}$

As shown in Figure 6a-6d, correlations between oxygenated cations and related neutral profiles support reactions (13), (A1), (A2) and (17) as the main production pathways in the preflame zone and flame zone. Similarly, their consumption reactions would be recombination reactions in post flame zone. Including these minor ion reactions should be the direction of future ion chemistry kinetic model development.

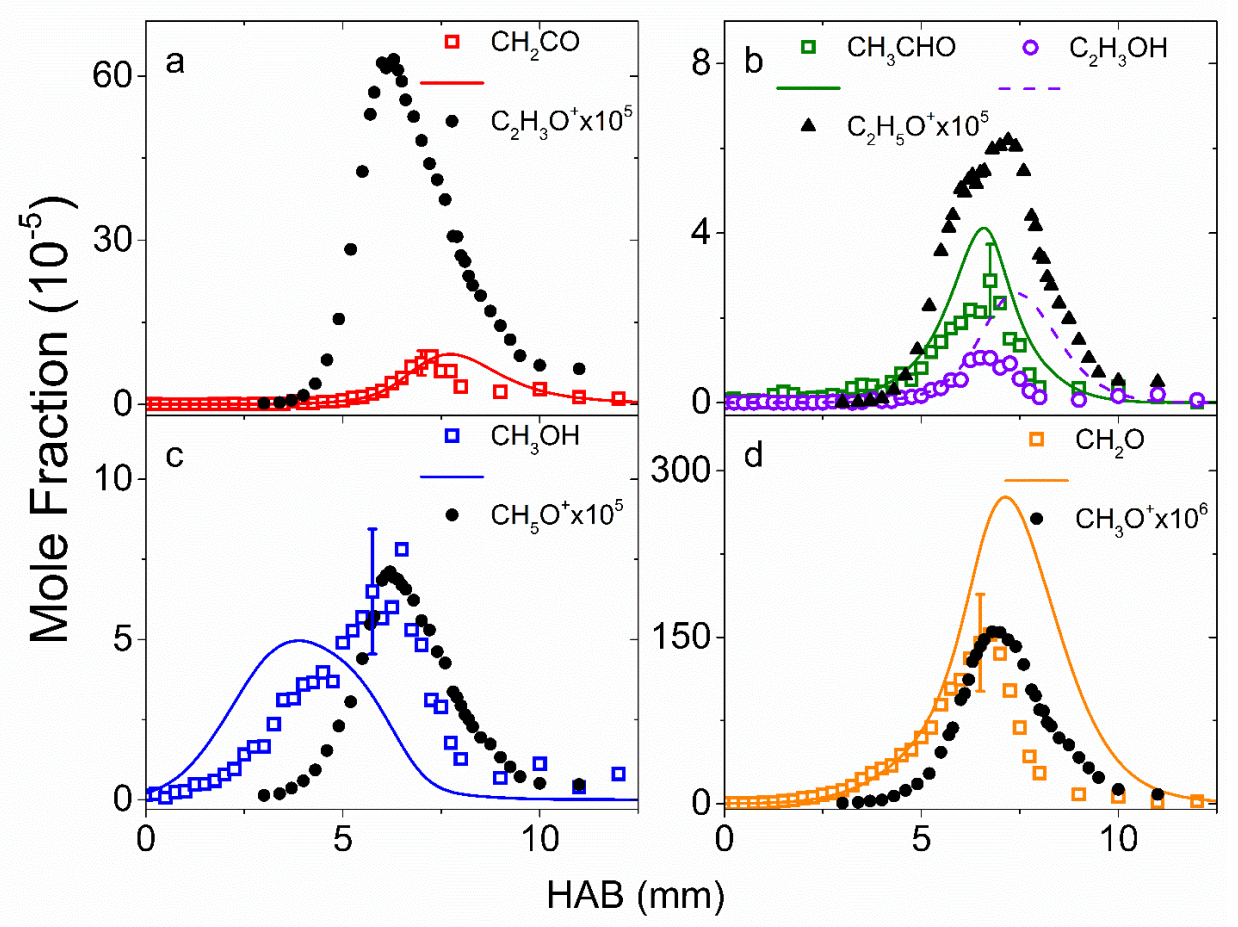

Figure $6 \mathrm{C}_{2} \mathrm{H}_{3} \mathrm{O}^{+}, \mathrm{C}_{2} \mathrm{H}_{5} \mathrm{O}^{+}, \mathrm{CH}_{5} \mathrm{O}^{+}$and $\mathrm{CH}_{3} \mathrm{O}^{+}$profiles and parent neutral profiles. Scatter points are experimental measured results while lines are numerical simulated results. Error bars are 
shown as $30 \%$ experimental uncertainty. $\mathrm{C}_{2} \mathrm{H}_{3} \mathrm{O}^{+}, \mathrm{C}_{2} \mathrm{H}_{5} \mathrm{O}^{+}, \mathrm{CH}_{5} \mathrm{O}^{+}$and $\mathrm{CH}_{3} \mathrm{O}^{+}$profiles are amplified by $10^{5}, 10^{5}, 10^{5}$ and $10^{6}$ for better comparison.

\subsubsection{Larger hydrocarbon cations}

The second most important and abundant hydrocarbon cations after $\mathrm{C}_{3} \mathrm{H}_{3}{ }^{+}$in rich flames is $\mathrm{C}_{4} \mathrm{H}_{5}{ }^{+} . \mathrm{C}_{4} \mathrm{H}_{5}{ }^{+}$may be produced through proton transfer and condensation-elimination reactions [31]:

$\mathrm{H}_{3} \mathrm{O}^{+}+\mathrm{C}_{4} \mathrm{H}_{4}<->\mathrm{C}_{4} \mathrm{H}_{5}{ }^{+}+\mathrm{H}_{2} \mathrm{O}$

$\mathrm{CH}_{3}{ }^{+}+\mathrm{C}_{3} \mathrm{H}_{4}<->\mathrm{C}_{4} \mathrm{H}_{5}{ }^{+}+\mathrm{H}_{2}$

The importance of reaction (A3) and (A4) as the main production pathway can be revealed by $\mathrm{C}_{4} \mathrm{H}_{5}{ }^{+}, \mathrm{C}_{3} \mathrm{H}_{4}$ and $\mathrm{C}_{4} \mathrm{H}_{4}$ profile comparisons. The results are shown in Figure 7. Measured allene $\left(\mathrm{C}_{3} \mathrm{H}_{4}-\mathrm{A}\right)$, propyne $\left(\mathrm{C}_{3} \mathrm{H}_{4}-\mathrm{P}\right)$ and vinyl-acetylene $\left(\mathrm{C}_{4} \mathrm{H}_{4}\right)$ profiles all correlate with $\mathrm{C}_{4} \mathrm{H}_{5}{ }^{+}$profiles, indicating both reaction (A3) and (A4) could be the main production pathways for $\mathrm{C}_{4} \mathrm{H}_{5}{ }^{+}$. $\mathrm{Allene}$ and propyne profiles are under predicted by a factor of two, and vinyl-acetylene profile is under predicted by a factor of thirty. This under prediction could be due to lack of species production pathways in the AramcoMech 2.0 model. 


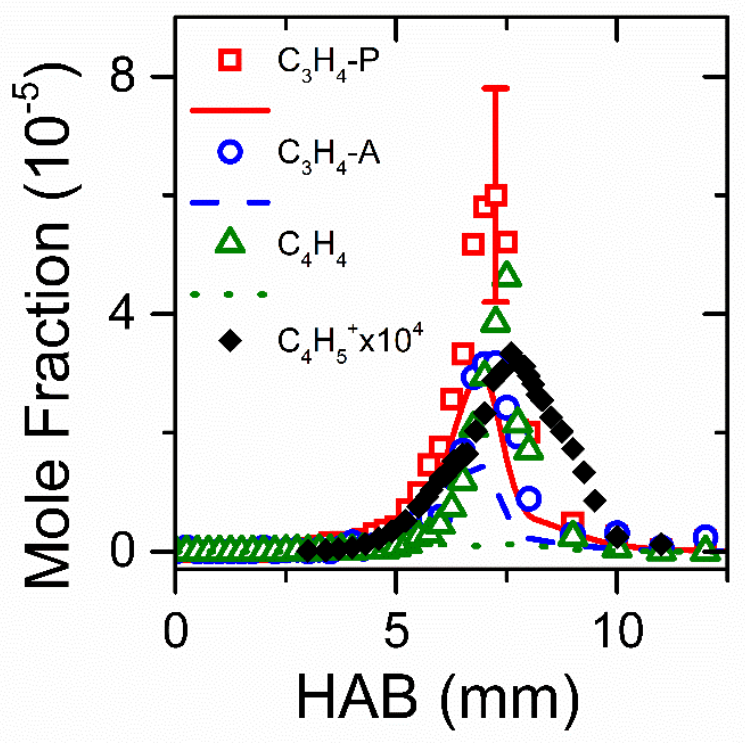

Figure $7 \mathrm{C}_{4} \mathrm{H}_{5}{ }^{+}$profiles and parent neutral profiles. Scatter points are experimental measured results while lines are numerical simulated results. Error bars are shown as 30\% experimental uncertainty. $\mathrm{C}_{4} \mathrm{H}_{5}+$ profiles are amplified by $10^{4}$ for better comparison.

Larger hydrocarbon cations, e.g. $\mathrm{C}_{5} \mathrm{H}_{3}{ }^{+}, \mathrm{C}_{5} \mathrm{H}_{5}{ }^{+}, \mathrm{C}_{6} \mathrm{H}_{5}{ }^{+}$and $\mathrm{C}_{7} \mathrm{H}_{7}+$, detected experimentally could be generated from $\mathrm{C}_{3} \mathrm{H}_{3}{ }^{+}$via carbon growth condensation-elimination reactions [31]:

$\mathrm{C}_{3} \mathrm{H}_{3}{ }^{+}+\mathrm{C}_{2} \mathrm{H}_{2}<->\mathrm{C}_{5} \mathrm{H}_{3}{ }^{+}+\mathrm{H}_{2}$

$\mathrm{C}_{3} \mathrm{H}_{3}{ }^{+}+\mathrm{C}_{2} \mathrm{H}_{2}<->\mathrm{C}_{5} \mathrm{H}_{5}^{+}$

$\mathrm{C}_{3} \mathrm{H}_{3}{ }^{+}+\mathrm{C}_{2} \mathrm{H}_{4}<->\mathrm{C}_{5} \mathrm{H}_{5}^{+}+\mathrm{H}_{2}$

$\mathrm{C}_{3} \mathrm{H}_{3}{ }^{+}+\mathrm{C}_{3} \mathrm{H}_{4}<->\mathrm{C}_{6} \mathrm{H}_{5}^{+}+\mathrm{H}_{2}$

$\mathrm{C}_{4} \mathrm{H}_{5}{ }^{+}+\mathrm{C}_{3} \mathrm{H}_{4}<->\mathrm{C}_{7} \mathrm{H}_{7}++\mathrm{H}_{2}$

Further carbon growth reactions could eventually produce polycyclic aromatic hydrocarbon ions and soot ions, as illustrated by Fialkov et al. [1]. Here we speculate one way soot may be 
suppressed by external electric field. When electric fields or plasmas are applied on flames, $\mathrm{C}_{3} \mathrm{H}_{3}{ }^{+}$ could be driven away from the reaction zone. Without $\mathrm{C}_{3} \mathrm{H}_{3}{ }^{+}$in the flame zone, polycyclic aromatic hydrocarbon ions and soot ions production pathways would be diminished. This could be a possible mechanism for soot suppression by electric field/plasma assisted combustion technologies. More investigations into ionic pathways to soot formation are required in the future work to support this speculation.

\section{Conclusions}

In this work, ion chemistry in rich methane premixed flames was systematically investigated. Cation and neutral profiles in four selected flames were experimentally measured by quadrupole MBMS and SVUV-PI-MBMS. Temperature profiles were measured by B-type thermocouple to illustrate flame zones and used for numerical simulations. After cations were detected and measured, their formula and dominant structures were revealed by literature survey $[14,16]$ and calculated thermodynamic properties.

After cation identification, proposed ion chemistry reaction schemes were discussed. $\mathrm{H}_{3} \mathrm{O}^{+}$ was observed to be the dominant ions in flame A, while $\mathrm{C}_{3} \mathrm{H}_{3}{ }^{+}$was the dominant one in flame $\mathrm{B}$ and C. Thirteen minor cations, e.g. $\mathrm{HCCO}^{+}, \mathrm{CH}_{3} \mathrm{O}^{+}, \mathrm{CH}_{5} \mathrm{O}^{+}, \mathrm{C}_{2} \mathrm{H}_{3} \mathrm{O}^{+}, \mathrm{C}_{2} \mathrm{H}_{5} \mathrm{O}^{+}$and $\mathrm{C}_{2} \mathrm{H}_{7} \mathrm{O}^{+}$are detected and identified as oxygenated cations; $\mathrm{C}_{3} \mathrm{H}_{5}^{+}, \mathrm{C}_{4} \mathrm{H}_{5}+\mathrm{C}_{5} \mathrm{H}_{3}{ }^{+}, \mathrm{C}_{5} \mathrm{H}_{5}+\mathrm{C}_{6} \mathrm{H}_{5}^{+}, \mathrm{C}_{6} \mathrm{H}_{7}^{+}$and $\mathrm{C}_{7} \mathrm{H}_{7}+$ as hydrocarbon cations. An updated kinetic model was proposed and utilized for numerical simulations, which successfully captured changes in cation dominance between $\mathrm{H}_{3} \mathrm{O}^{+}$and $\mathrm{C}_{3} \mathrm{H}_{3}{ }^{+}$ at different equivalence ratios in flame $\mathrm{A}, \mathrm{B}$ and $\mathrm{C}$.

To further reveal and verify ion-neutral reaction pathways, neutral profiles measured by SVUV-PI-TOF-MBMS were compared with cation profiles to assess possible ion-neutral 
reactions. Comparisons between cation and neutral profiles supported our proposed ion-neutral reaction pathways. This work provided detailed measurements for rich methane flames, proposed an updated ion chemistry mechanism, and thereby promotes future ion chemistry model development.

\section{Acknowledgement}

The research reported in this publication was supported by funding from King Abdullah University of Science and Technology (KAUST) and the Clean Combustion Research Center (CCRC). NH acknowledges support from the U.S. DOE, Office of Science, Office of Basic Energy Sciences. Sandia National Laboratories is a multi-mission laboratory managed and operated by National Technology and Engineering Solutions of Sandia, LLC., a wholly owned subsidiary of Honeywell International, Inc., for the U.S. DOE National Nuclear Security Administration under contract DE-NA0003525. The Advanced Light Source is supported by the Director, Office of Science, Office of Basic Energy Sciences, of the U.S. DOE under Contract No. DEAC02$05 \mathrm{CH} 11231$.

\section{References}

1. A.B. Fialkov, Investigations on ions in flames, Prog. Energy Combust. Sci. 23 (1997) 399-528.

2. M. Hellring, T. Munther, T. Rögnvaldsson, N. Wickström, C. Carlsson, M. Larsson, J. Nytomt, Spark advance control using the ion current and neural soft sensors, SAE International. 1999-01-1162 (1999).

3. M. Asano, T. Kuma, M. Kajitani, M. Takeuchi, Development of new ion current combustion control system, SAE International. 980162 (1998).

4. A. Gazis, D. Panousakis, R. Chen, W.-H. Chen, Computationally inexpensive methods of ion current signal manipulation for predicting the characteristics of engine in-cylinder pressure, Int. J. Engine Res. 7 (2006) 271-282.

5. H. Calcote, J. Reuter, Mass - Spectrometric Study of lon Profiles in Low - Pressure Flames, J. Chem. Phys. 38 (1963) 310-317.

6. H.F. Calcote, R.N. Pease, Electrical Properties of Flames. BurnerFlames in Longitudinal Electric Fields, Ind. Eng. Chem. 43 (1951) 2726-2731. 
7. J.M. Goodings, D.K. Bohme, C.-W. Ng, Detailed ion chemistry in methane oxygen flames. II. Negative ions, Combust. Flame 36 (1979) 45-62.

8. J.M. Goodings, D.K. Bohme, C.-W. Ng, Detailed ion chemistry in methane oxygen flames. I. Positive ions, Combust. Flame 36 (1979) 27-43.

9. J. Deckers, A. Van Tiggelen, lon identification in flames by mass spectrometry, Nature 181 (1958) 1460-1460.

10. J. Deckers, A. Van Tiggelen, Identity of Ions in Some Flames, Nature 182 (1958) 863-863.

11. M. Saito, T. Arai, M. Arai, Control of soot emitted from acetylene diffusion flames by applying an electric field, Combust. Flame 119 (1999) 356-366.

12. A. Hayhurst, H. Jones, Chemi-ionization in oxyacetylene flames, Nature 296 (1982) 61.

13. A.N. Hayhurst, H.R. Jones, lons and soot in flames, J. Chem. Soc. Faraday Trans. 83 (1987) 1-27.

14. H.R. Jones, A.N. Hayhurst, Measurements of the concentrations of positive and negative ions along premixed fuel-rich flames of methane and oxygen, Combust. Flame 166 (2016) 86-97.

15. A. Fialkov, K.Y. Kalinich, B. Fialkov, Experimental determination of primary ions in flame, Symp. (Int.) Combust. 24 (1992) 785-791.

16. A.B. Alquaity, B. Chen, J. Han, H. Selim, M. Belhi, Y. Karakaya, T. Kasper, S.M. Sarathy, F. Bisetti, A. Farooq, New insights into methane-oxygen ion chemistry, Proc. Combust. Inst. 36 (2017) 12131221.

17. A.B. Alquaity, J. Han, M. Chahine, H. Selim, M. Belhi, S.M. Sarathy, F. Bisetti, A. Farooq, Measurements of positively charged ions in premixed methane-oxygen atmospheric flames, Combust. Sci. Technol. 189 (2017) 575-594.

18. J. Prager, U. Riedel, J. Warnatz, Modeling ion chemistry and charged species diffusion in lean methane-oxygen flames, Proc. Combust. Inst. 31 (2007) 1129-1137.

19. T. Pedersen, R.C. Brown, Simulation of electric field effects in premixed methane flames, Combust. Flame 94 (1993) 433-448.

20. J.M. Goodings, C.S. Hassanali, P.M. Patterson, C. Chow, A new flame-ion mass spectrometer: chemi-ionizatino of lanthanum observed in hydrogen-oxygen-argon flames, International Journal of Mass Spectrometry and Ion Processes 132 (1994) 83-96.

21. T.A. Cool, K. Nakajima, C.A. Taatjes, A. Mcllroy, P.R. Westmoreland, M.E. Law, A. Morel, Studies of a fuel-rich propane flame with photoionization mass spectrometry, Proc. Combust. Inst. 30 (2005) 1681-1688.

22. C.R. Shaddix, Correcting thermocouple measurements for radiation loss: a critical review, Sandia National Laboratories, Livermore, CA, USA, 1999.

23. N. Hansen, T.A. Cool, P.R. Westmoreland, K. Kohse-Höinghaus, Recent contributions of flamesampling molecular-beam mass spectrometry to a fundamental understanding of combustion chemistry, Prog. Energy Combust. Sci. 35 (2009) 168-191.

24. A. Lucassen, N. Labbe, P.R. Westmoreland, K. Kohse-Höinghaus, Combustion chemistry and fuelnitrogen conversion in a laminar premixed flame of morpholine as a model biofuel, Combust. Flame 158 (2011) 1647-1666.

25. H. Selim, S.Y. Mohamed, A. Lucassen, N. Hansen, S.M. Sarathy, Effect of the methyl substitution on the combustion of two methylheptane isomers: Flame chemistry using vacuum-ultraviolet (VUV) photoionization mass spectrometry, Energy Fuel 29 (2015) 2696-2708.

26. H. Selim, S.Y. Mohamed, N. Hansen, S.M. Sarathy, Premixed flame chemistry of a gasoline primary reference fuel surrogate, Combust. Flame 179 (2017) 300-311.

27. F.N. Egolfopoulos, N. Hansen, Y. Ju, K. Kohse-Höinghaus, C.K. Law, F. Qi, Advances and challenges in laminar flame experiments and implications for combustion chemistry, Prog. Energy Combust. Sci. 43 (2014) 36-67. 
28. Y. Li, C.-W. Zhou, K.P. Somers, K. Zhang, H.J. Curran, The oxidation of 2-butene: A high pressure ignition delay, kinetic modeling study and reactivity comparison with isobutene and 1-butene, Proc. Combust. Inst. 36 (2017) 403-411.

29. D. McElroy, C. Walsh, A. Markwick, M. Cordiner, K. Smith, T. Millar, The UMIST database for astrochemistry 2012, Astron. Astrophys. 550 (2013) A36.

30. J. Cancian, B. Bennett, M. Colket, M. Smooke, Prediction of electron and ion concentrations in low-pressure premixed acetylene and ethylene flames, Combust. Theor. Model. 17 (2013) 294315.

31. A.N. Eraslan, R.C. Brown, Chemiionization and ion-molecule reactions in fuel-rich acetylene flames, Combust. Flame 74 (1988) 19-37.

32. A.D. Becke, Density - functional thermochemistry. III. The role of exact exchange, J. Chem. Phys. 98 (1993) 5648-5652.

33. C. Lee, W. Yang, R.G. Parr, Development of the Colle-Salvetti correlation-energy formula into a functional of the electron density, Phys. Rev. B 37 (1988) 785.

34. J.A. Montgomery Jr, M.J. Frisch, J.W. Ochterski, G.A. Petersson, A complete basis set model chemistry. VII. Use of the minimum population localization method, J. Chem. Phys. 112 (2000) 6532-6542.

35. J.W. Ochterski, G.A. Petersson, J.A. Montgomery Jr, A complete basis set model chemistry. V. Extensions to six or more heavy atoms, J. Chem. Phys. 104 (1996) 2598-2619.

36. M. Frisch, G. Trucks, H. Schlegel, G. Scuseria, M. Robb, J. Cheeseman, G. Scalmani, V. Barone, B. Mennucci, G. Petersson, Gaussian 09. 2009, Gaussian, Inc.: Wallingford, CT, USA, 542, 1990.

37. A. Burcat, E. Goos, The Ideal Gas Thermochemistry of Oxonium Cations, J. Chem. Eng. Data 61 (2016) 1361-1367.

38. C. Sheng, Elementary, pressure dependent model for combustion of C (1), C (2) and nitrogencontaining hydrocarbons: Operation of a pilot-scale incinerator and model comparison, New Jersey Institute of Technology, PhD thesis, 2004.

39. R.D. Johnson III, NIST 101. Computational Chemistry Comparison and Benchmark Database, 1999.

40. T.H. Lay, L.N. Krasnoperov, C.A. Venanzi, J.W. Bozzelli, N.V. Shokhirev, Ab Initio Study of $\alpha-$ Chlorinated Ethyl Hydroperoxides $\mathrm{CH} 3 \mathrm{CH} 2 \mathrm{OOH}, \mathrm{CH} 3 \mathrm{CHClOOH}$, and $\mathrm{CH} 3 \mathrm{CCl} 2 \mathrm{OOH}$ : Conformational Analysis, Internal Rotation Barriers, Vibrational Frequencies, and Thermodynamic Properties, J. Phys. Chem. 100 (1996) 8240-8249.

41. J. Han, M. Belhi, F. Bisetti, S. Mani Sarathy, Numerical modelling of ion transport in flames, Combust. Theor. Model. 19 (2015) 744-772.

42. P. Oßwald, Systematische Analyse der Verbrennungsprozesse oxygenierter Brennstoffe mittels Molekularstrahlmassenspektrometrie, Chemistry Department, Bielefeld University, PhD thesis, 2009.

43. A. Chemkin-Pro, 18.0, ANSYS Reaction Design: San Diego, 2017.

44. R.C. Brown, A.N. Eraslan, Simulation of ionic structure in lean and close-to-stoichiometric acetylene flames, Combust. Flame 73 (1988) 1-21. 